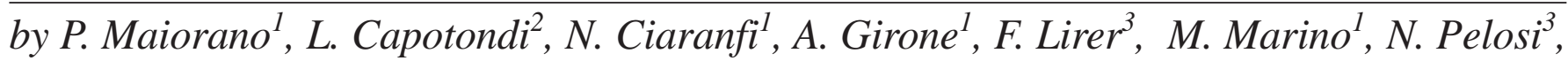
P. Petrosino ${ }^{4}$, and A. Piscitelli ${ }^{1}$

\title{
Vrica-Crotone and Montalbano Jonico sections: A potential unit-stratotype of the Calabrian Stage
}

\author{
${ }^{1}$ Dipartimento di Geologia e Geofisica, Università degli Studi di Bari “Aldo Moro”, via E. Orabona 4, 70125 Bari, Italy. \\ E-mail: p.maiorano@geo.uniba.it \\ ${ }^{2}$ Istituto di Scienze Marine, CNR, via Gobetti 101, 40129 Bologna, Italy \\ ${ }^{3}$ Istituto per l'Ambiente Marino Costiero (IAMC) Sede Napoli - CNR, Calata Porta di Massa, Interno Porto di Napoli, 80133, Napoli, Italy \\ ${ }^{4}$ Dipartimento di Scienze della Terra, Universita‘ degli Studi di Napoli Federico II, L.go San Marcellino 10, 80138 Napoli, Italy
}

A unique composite record from the Mediterranean area exposed on land and spanning the entire time interval of the Calabrian Stage is presented. The record is composed of the Vrica-Crotone section (Calabria, southern Italy) and the Montalbano Jonico section (Basilicata, southern Italy). The Vrica-Crotone section contains the proposed Global Stratotype Section and Point (GSSP) of the Calabrian Stage and extends from Marine Isotope Stage (MIS) 65 to 37 for its Calabrian portion. The Montalbano Jonico section extends from MIS 37 to 17-16. Its upper portion contains MIS 19, which is known to occur close to the Matuyama/Brunhes reversal, and may represent a suitable horizon for the definition of the GSSP of the 'Ionian'Stage. Both sections are astronomically tuned, thus providing accurate ages for the bioevents. New biostratigraphic results and radiometric data on volcaniclastic layer V3 of the Montalbano Jonico section are presented together with an updated tuning of the section. A comparison with several Mediterranean and north Atlantic deepsea cores is also shown to verify the consistency and reliability of the biostratigraphic data. The Vrica-Crotone and Montalbano Jonico sections can be considered a suitable composite record for the Calabrian unitstratotype and support the revaluation of the unitstratotype concept in addition to the GSSP approach.

\section{Introduction}

The Stage is the basic working unit in chronostratigraphy and represents the lowest rank in the standard chronostratigraphic hierarchy recognizable at global scale. It is defined within a boundarystratotype, by a Global Boundary Stratotype Section and Point (GSSP) (Salvador, 1994). The GSSP concept was introduced in order to avoid the problem of uncertainties both in time correlation (gaps and/or overlaps) between historical stages and in their continuity, thus emphasizing the role of boundaries rather than the content for the definition of the stage. An exhaustive review of the history and application of the concept of GSSPs can be found in Aubry et al. (1999) and Walsh et al. (2004). The concept of the unit-stratotype (a continuously exposed section, in facies favourable for timecorrelation, extending from the lower boundary-stratotype to an upper boundary-stratotype), initially introduced by Hedberg (1958), has been recently re-interpreted and advocated by Hilgen et al. (2006) with particular attention to Neogene units in the Mediterranean area, and by Cita and Pillans (2010). Recent progress in integrated highresolution stratigraphy and astronomical tuning of sedimentary cycles, in fact, offers the opportunity to define the stages in continuous, cyclic and well-tuned successions. These sections may also serve as unit-stratotypes, thus providing precision and accuracy throughout the entire stage. Consequently, the stage should not just be defined by its boundaries (GSSPs) but also by its content (Hilgen et al., 2006). The Capo Rossello composite section, which contains both Zanclean and Piacenzian GSSPs, represents a prime example of the unit-stratotype approach and several other Pliocene and Miocene examples are known and summarized in Hilgen et al. (2006). On the other hand, formalization of Pleistocene stages is still in progress. After a Special Symposium on the Quaternary (chairs M.B. Cita and B. Pillans) during the International Geological Congress of Oslo (2008), the International Union of Geological Sciences (IUGS), on June 30, 2009, ratified the redefinition of the base of the Quaternary System/Period (and top of the Neogene System/Period), and the redefinition of the base of the Pleistocene Series/Epoch (and top of the Pliocene Series/Epoch) following the proposal of Head et al. (2008a). In detail, the base of the Quaternary System/Period and of the Pleistocene Series/Epoch were lowered to the GSSP of the Gelasian Stage formally defined at Monte San Nicola, Sicily, Italy (Gibbard et al., 2010) dated at 2.6 Ma. With these definitions, the Gelasian Stage/Age shifts from the Pliocene Series/Epoch to the Pleistocene. Several controversial positions have been conveyed in the last two years concerning this issue (i.e., Head et al., 2008a; Walsh, 2008; Aubry et al., 2009; McGowran et al., 2009; Rio et al., 2010) revealing the strong significance of Plio-Pleistocene chronostratigraphy for the international scientific community. If the Gelasian represents the first stage of the revisited Pleistocene, a redefinition of the second stage of this Series, the Calabrian Stage, becomes necessary, as recently proposed by Cita et al. (2008). The proposed Calabrian 
GSSP corresponds to the GSSP where the Plio/Pleistocene boundary was ratified by IUGS in 1984 in the Vrica section. It was placed at the top of sapropel "e", with an astronomical age of $1.806 \mathrm{Ma}$ (Lourens et al., 2004), in the latest part of the Olduvai Subchron. The top of the Calabrian Stage is coincident with the successive 'Ionian' Stage which still lacks a formal definition. Cita et al. (2008) asserted that a continuous stratigraphical interval representing the entire time interval of the Calabrian Stage is so far known only from deep-sea sequences recovered in the Mediterranean Ocean Drilling Program (ODP) Legs 107, 160, 161.

In this paper, based on new data collected in the Montalbano Jonico section, we present a composite Mediterranean record, exposed on land, spanning the entire time interval of the Calabrian Stage, which may represent a potential unit-stratotype of that stage. We are well aware that only GSSPs are accepted and considered mandatory by IUGS for global stage definition, nevertheless we consider appropriate the reconsideration of the unit-stratotype notion as complementary to the GSSP concept. A stage is, in fact, the sedimentary representation ("time-rock unit" in Chronostratigraphy) of the equivalent time unit (Geochronology): "the best standard for a chronostratigraphic unit is a body of rocks formed between two designated instants of geologic time" (Salvador, 1994, p. 88). Continuous land-based marine records yielding high-resolution stratigraphy and accurate chronology may be valuable reference sections for the entire stage. These records may be the needful basis for the selection of the best GSSP as well as helpful in the geological practice. It is for these reasons that, although no formal definition of the Calabrian and 'Ionian' Stages has been ratified yet, and accordingly, their use is still somewhat inappropriate, we consider constructive to illustrate the continuous land-based marine record which describes the "content" of the potential Calabrian Stage and which may accommodate two consecutive potential GSSPs. The record is composed of the Vrica-Crotone and Montalbano Jonico sections (Figure 1), both astronomically tuned and with high resolution integrated biostratigraphy. The on-land records are compared with Mediterranean and extra-Mediterranean deep-sea records, in order to explore the consistency and reliability of the cyclostratigraphic and biostratigraphic data. Finally, a potential GSSP for the 'Ionian' Stage is also suggested in the Montalbano Jonico section.

\section{A potential unit-stratotype of the Calabrian Stage}

The composite record consisting of the Vrica-Crotone and Montalbano Jonico sections encompasses the entire Calabrian Stage. For the Vrica-Crotone section we summarize the most significant data following the astronomical calibration provided by Lourens et al. (1996; 1998); whereas we present new biostratigraphic and radiometric data for the Montalbano Jonico section.

The Calabrian interval is well documented in several deep-sea sequences; therefore the overall data are compared using Mediterranean and oceanic deep-sea records (ODP Site 967; ODP Site 964; Core KC01B and Deep Sea Drilling Project - DSDP Site 607) (Figure 1; Table 1). For the coeval interval recovered from the Vrica-Crotone section we consider ODP Site 967 (Emeis et al., 1996), representing an Eastern Mediterranean deep-sea sequence, whose
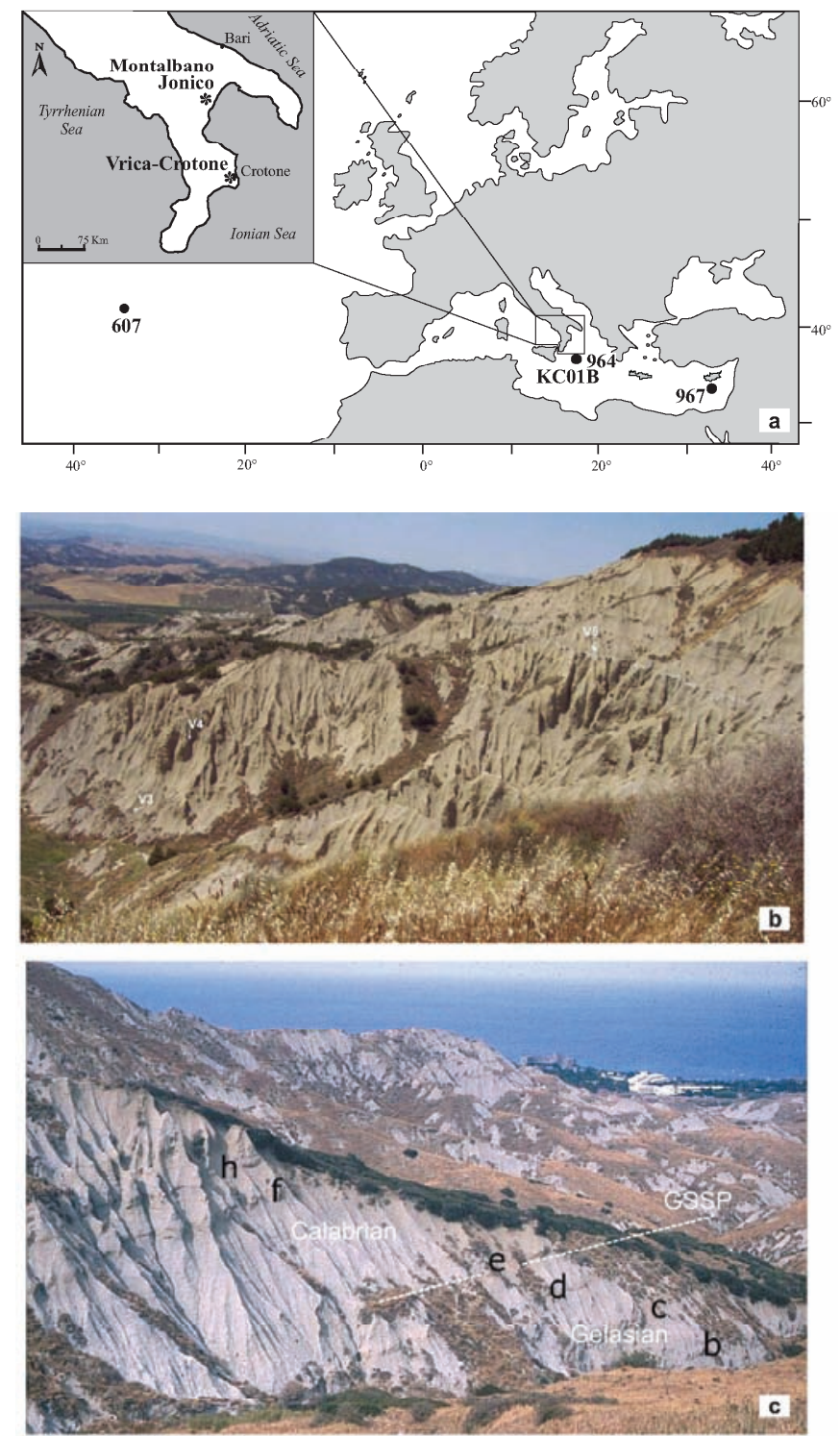

Figure 1. (a) Geographic location map of the sections considered in this study; (b) Lithological sequence of Montalbano Jonico section showing position of main volcaniclastic layers $(V)$; (c) Lithological sequence of $B$ segment of Vrica section showing the sapropel layers: $b, c, d, e, f$ and $h$, (modified from ICS web site www.stratigraphy.org). The GSSP of the Calabrian Stage is fixed (dashed line) at the top of level "e" according to Cita et al. (2008).

sapropel pattern and biostratigraphic data have been correlated to the Vrica section (Lourens et al., 1998). ODP Site 964 (Emeis et al., 1996) and Core KC01B, both located in the Ionian Basin, have been considered for the interval recovered by the Montalbano Jonico section. The chronology of these sections follows the recent astronomical re-calibration by Lourens (2004). Finally, we consider DSDP Site 607 as a mid-latitude North Atlantic reference deep-sea section. The oxygen isotope chronology adopted for the core follows recalibration to the LR04 timescale of Lisiecki and Raymo (2005).

\section{Vrica-Crotone section}

The well known Vrica-Crotone section exposes the lower part of the Calabrian Stage (Figure 2). This section, located in northern 
Table 1. Summary of the sections considered in this study and relative references considered in the present paper

\begin{tabular}{|c|c|c|c|c|c|c|}
\hline \multicolumn{2}{|c|}{ SECTION } & \multicolumn{5}{|c|}{ REFERENCE } \\
\hline Section or Leg/Site & Location & $\begin{array}{l}\text { Biostratigraphy } \\
\text { Biochronology }\end{array}$ & $\begin{array}{l}\text { Oxygen isotope } \\
\text { stratigraphy }\end{array}$ & $\begin{array}{l}\text { Magneto- } \\
\text { stratigraphy }\end{array}$ & $\begin{array}{l}\text { Tephra- } \\
\text { chronology }\end{array}$ & $\begin{array}{l}\text { Age } \\
\text { Model }\end{array}$ \\
\hline Vrica-Crotone & $\begin{array}{l}\text { Calabria } \\
\text { (Southern Italy) }\end{array}$ & Lourens et al. $(1996,1998)$ & $\begin{array}{l}\text { Lourens et al. (1996, } \\
1998)\end{array}$ & $\begin{array}{l}\text { Zijderveld et al. } \\
\text { (1991) }\end{array}$ & & $\begin{array}{l}\text { Lourens et al. } \\
(1996,1998)\end{array}$ \\
\hline Montalbano Jonico & $\begin{array}{l}\text { Basilicata } \\
\text { (Southern Italy) }\end{array}$ & $\begin{array}{l}\text { Marino (1996) } \\
\text { Maiorano et al. (2004) } \\
\text { This study } \\
\text { Ciaranfi et al. (2010) } \\
\text { This study }\end{array}$ & $\begin{array}{l}\text { Brilli et al. (2000) } \\
\text { Ciaranfi et al. (2001) } \\
\text { Ciaranfi et al. (2010) }\end{array}$ & $\begin{array}{l}\text { Sagnotti et al. } \\
\text { (2010) }\end{array}$ & $\begin{array}{l}\text { Ciaranfi et al. } \\
\text { (2010) } \\
\text { this study }\end{array}$ & $\begin{array}{l}\text { Ciaranfi et al. } \\
(2010) \\
\text { this study }\end{array}$ \\
\hline ODP $160 /$ Site 967 & $\begin{array}{l}\text { Eastern } \\
\text { Mediterranean }\end{array}$ & $\begin{array}{l}\text { Lourens et al. (1998) } \\
\text { Raffi (2002) }\end{array}$ & Kroon et al. (1998) & & & $\begin{array}{l}\text { Lourens et al. } \\
\text { (1998) }\end{array}$ \\
\hline ODP $160 /$ Site 964 & Ionian Sea & $\begin{array}{l}\text { Maiorano and Marino (2004) } \\
\text { This study }\end{array}$ & $\begin{array}{l}\text { Howell et al. (1998) } \\
\text { Sprovieri et al. (1998) }\end{array}$ & & & Lourens (2004) \\
\hline Core $\mathrm{KC} 01 \mathrm{~B}$ & Ionian Sea & $\begin{array}{l}\text { Castradori (1992); this study } \\
\text { This study }\end{array}$ & $\begin{array}{l}\text { Rossignol-Strick et al. } \\
\text { (1998) }\end{array}$ & & & Lourens (2004) \\
\hline DSDP 94/Site 607 & North Atlantic & $\begin{array}{l}\text { Ruddimann et al. (1989) } \\
\text { Raffi (2002) } \\
\text { Maiorano and Marino (2004) } \\
\text { This study }--------\end{array}$ & Ruddimann et al. (1989) & & & $\begin{array}{l}\text { Lisiecki and } \\
\text { Raymo (2005) }\end{array}$ \\
\hline
\end{tabular}

Calabria (southern Italy) has been intensively investigated in the past (Selli et al., 1977; Colalongo et al., 1980; Pasini and Colalongo, 1982; Tauxe et al., 1983; Backman et al., 1983; Aguirre and Pasini, 1985; Bassett, 1985; Howell et al., 1990; Zijderveld et al., 1991; Azzaroli et al., 1996; Lourens et al., 1996; Rio et al., 1997; Lourens et al., 1998). Recently, new papers on the Vrica-Crotone section (Suc et al., 2010; Roberts et al., 2010) reveal a continuous scientific interest for this section. It is a well exposed composite section (Figure 1), about $240 \mathrm{~m}$ thick, consisting of grey to blue-coloured, marly to silty marine clays. Several sapropel layers occur in the section that were mostly labelled "a" to "t" by Selli et al. (1977). Occasionally, ash beds are present. The uppermost part of the section, which accommodates sapropels "u" and "v" (Figure 2), extends into the Crotone section which is cyclostratigraphically correlated to the Vrica section (Zijderveld et al., 1991; Lourens et al., 1996). The Vrica section was formally designated as the reference for the GSSP of the Pleistocene Series as ratified by IUGS in 1984 (Aguirre and Pasini, 1985; Bassett, 1985). Specifically, the Pliocene-Pleistocene boundary was defined at the top of sapropel "e" which was the primary marker for the recognition of the boundary (Figure 1). After the recent redefinition of the base of the Pleistocene Series at the base of the Gelasian Stage $(2.6 \mathrm{Ma})$, the top of sapropel "e" at Vrica section and the GSSP of the Pleistocene were disconnected (Figure 2). Afterwards, the historical Pliocene/Pleistocene boundary of the Vrica section has been proposed as the GSSP of the Calabrian Stage (Cita et al., 2008). Indeed, the 'Quaternary' proposal had intended the Calabrian Stage to be defined by the GSSP at the Vrica section (Gibbard and Head 2009; Gibbard and Head, 2010). It is located about 10 meters below the top of the Olduvai magnetozone (Zijderveld et al., 1991), at the transition between MIS 65 and 64 (Lourens et al., 1996; Lourens et al., 1998). From a biostratigraphic point of view, the boundary almost coincides with the Lowest Common Occurrence (LCO) of Neogloboquadrina pachyderma left-coiling (Figure 2) and falls between the Highest Occurrence (HO) of Discoaster brouweri and the Lowest Occurrence (LO) of medium-sized Gephyrocapsa (Lourens et al., 1996; Lourens et al., 1998). By tuning the sapropel pattern to the summer insolation time series using the astronomical solution of Laskar et al. (1993, 2004), an age of 1.806 Ma has been assigned to the boundary (Lourens et al., 2004). The astronomical calibration available for the Vrica-Crotone section reveals that the Calabrian portion is continuous, spanning the interval from 1.81 to 1.22 Ma, and provides accurate ages of the biostratigraphic events, sapropels and magnetostratigraphic data (Figure 2). Cyclostratigraphy and biochronology of the Vrica-Crotone section was presented by Lourens et al. (1996) and Lourens et al. (1998) to which we refer (Table 2).

\section{Montalbano Jonico section}

The Montalbano Jonico section represents a unique and valuable record of the upper portion of the Calabrian Stage exposed on-land. Several integrated stratigraphic studies have been carried out on the Montalbano Jonico section (e.g. Ciaranfi et al., 2001; D'Alessandro et al., 2003; Stefanelli, 2003; Maiorano et al., 2004), located in the Lucania Basin (Balduzzi et al., 1982). The section is about $450 \mathrm{~m}$ thick (Figure 3), consists of coarsening-upwards deposits from silty clays to silty sands and includes five "sapropel" layers (Stefanelli, 2004; Stefanelli et al., 2005; Maiorano et al., 2008) and nine volcaniclastic layers (V1-V9).

Based on calcareous nannoplankton (Ciaranfi et al., 1996; Marino, 1996; Maiorano et al., 2004) the section belongs to the small Gephyrocapsa and Pseudoemiliana lacunosa zones of Rio et al. (1990). New quantitative data have been collected on planktonic foraminifera from the lower part of Montalbano section with special regards to N. pachyderma left-coiling and Globorotalia crassaformis distribution patterns (Figure 3). The high-resolution sampling of 


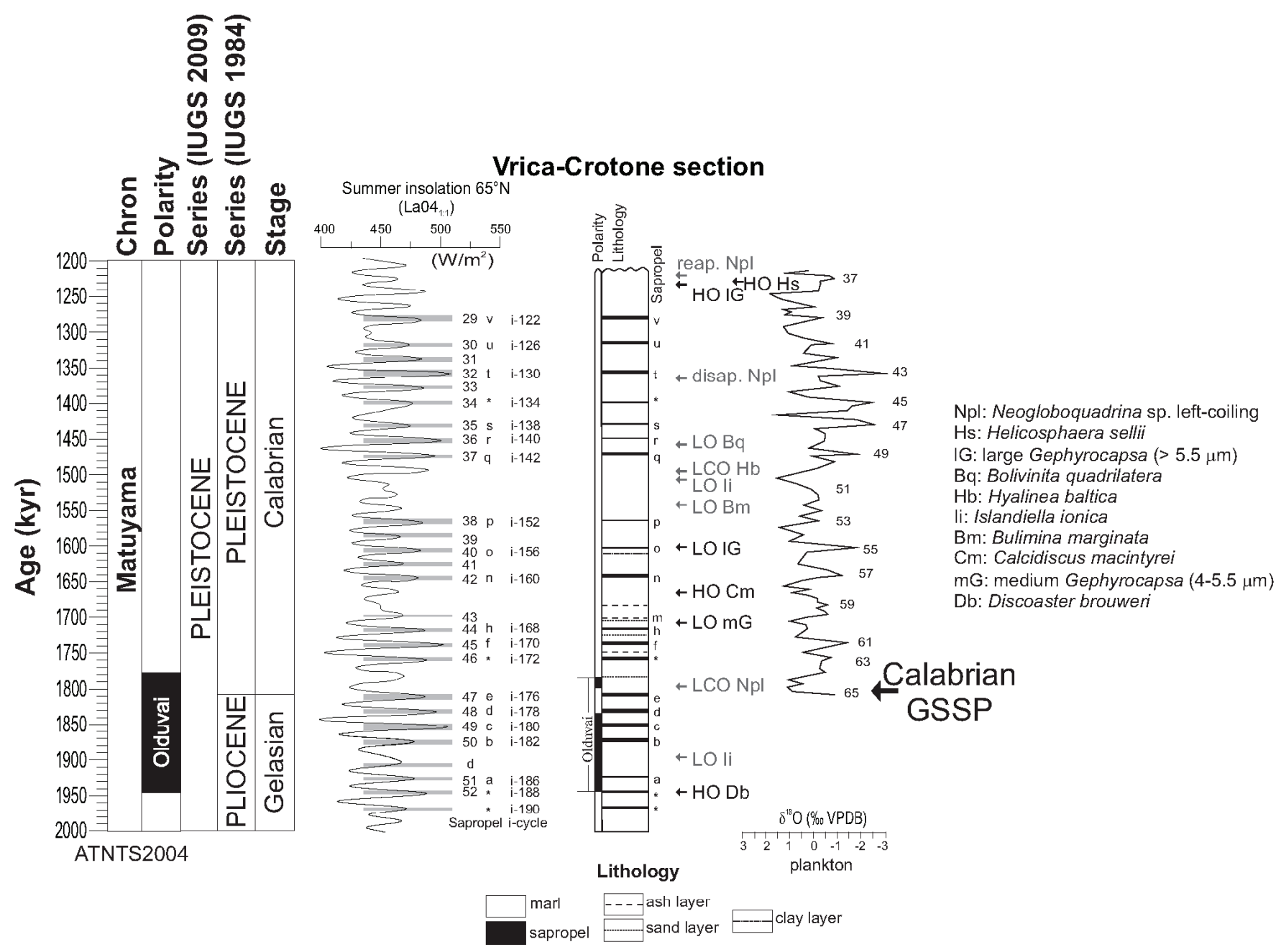

Figure 2. Astronomical calibration, oxygen isotope chronology and bioevents at Vrica-Crotone section according to the continuous age model of Lourens et al. (1996). Magnetostratigraphy is from Zijderveld et al. (1991); lithostratigraphy from Selli et al. (1977), Zijderveld et al. (1991), Lourens et al. (1996). Astronomical Time Scale (ATNTS2004) from Lourens et al. (2004); summer insolation 65 ${ }^{\circ}$ (La04 $\left.{ }_{1: 1}\right)$ from Laskar et al. (2004). LO: Lowest Occurrence; LCO: Lowest Common Occurrence; HO: Highest Occurrence; reap.: reappearance; disap.: disappearance.

1-2 ky allowed identification of two additional planktonic foraminiferal bioevents: the reappearance of $N$. pachyderma left-coiling and the influx of G. crassaformis. N. pachyderma left-coiling is absent or rare in the lowermost part of the section, while distinct peaks are recorded from $17.2 \mathrm{~m}$ upwards, where we identify the reappearance of the taxon (Figure 3). The event occurs below sapropel 28 (i-cycle 112 ) and is correlated to MIS 36 (Figure 3). Upwards, a short influx of G. crassaformis has been recognized from 50.15 to $60.55 \mathrm{~m}$, slightly below sapropel 26 (i-cycle 104), within MIS 34 (Figure 3). The calcareous nannofossil bioevents (Figure 3) are represented by Lowest Common Occurrence (LCO) and Highest Common Occurrence (HCO) of Reticulofenestra asanoi, Lowest Occurrence (LO) and temporary disappearance interval (td2 interval in Maiorano and Marino, 2004) of Gephyrocapsa omega and have been already presented in previous papers (Maiorano et al., 2004; Ciaranfi et al., 2010). The LCO of $R$. asanoi is located just above sapropel 25 (icycle 102) and within MIS 31, while the HCO of this species correlates with i-cycle 86 and MIS 23 (Figure 3). The LO of G. omega is recorded within sapropel 19 (i-cycle 90) and MIS 25 and the temporary disappearance interval (td2 interval) extends from MIS 21- 20 to 19-
18 (Figure 3). New data on temporal distribution patterns have been obtained on these calcareous events from other Mediterranean deepsea records and are presented below.

Rigorous magnetostratigraphic investigations have revealed that the magnetic signal in the Montalbano Jonico section is unreliable due to remagnetization of the entire section (Sagnotti et al., 2010). On the other hand, the sapropel pattern, together with the ${ }^{39} \mathrm{Ar} /{ }^{40} \mathrm{Ar}$ age of the volcaniclastic layer V5, the calcareous plankton biostratigraphic constraints, and oxygen isotope records have allowed an astronomical calibration of the section (Ciaranfi et al., 2010). In addition, a new ${ }^{39} \mathrm{Ar} /{ }^{40} \mathrm{Ar}$ age was recently obtained on volcaniclastic layer V3. Full chemical data on glass shards from this volcaniclastic layer could not be obtained, owing to the strong alteration involving the fragments (Ciaranfi et al., 2010), but well preserved sanidine crystal grains were selected and radiometric dating was carried out at the Department of Geology and Geophysics of the University of Wisconsin in Madison. Irradiation, analysis and general interpretive principles are described in detail by Smith et al. (2008). The age of V3 layer is $801.2 \pm 19.5 \mathrm{ka}$ (Figure 4). This age is fully consistent with the stratigraphic position of V3 layer, since it crops out $121.9 \mathrm{~m}$ 

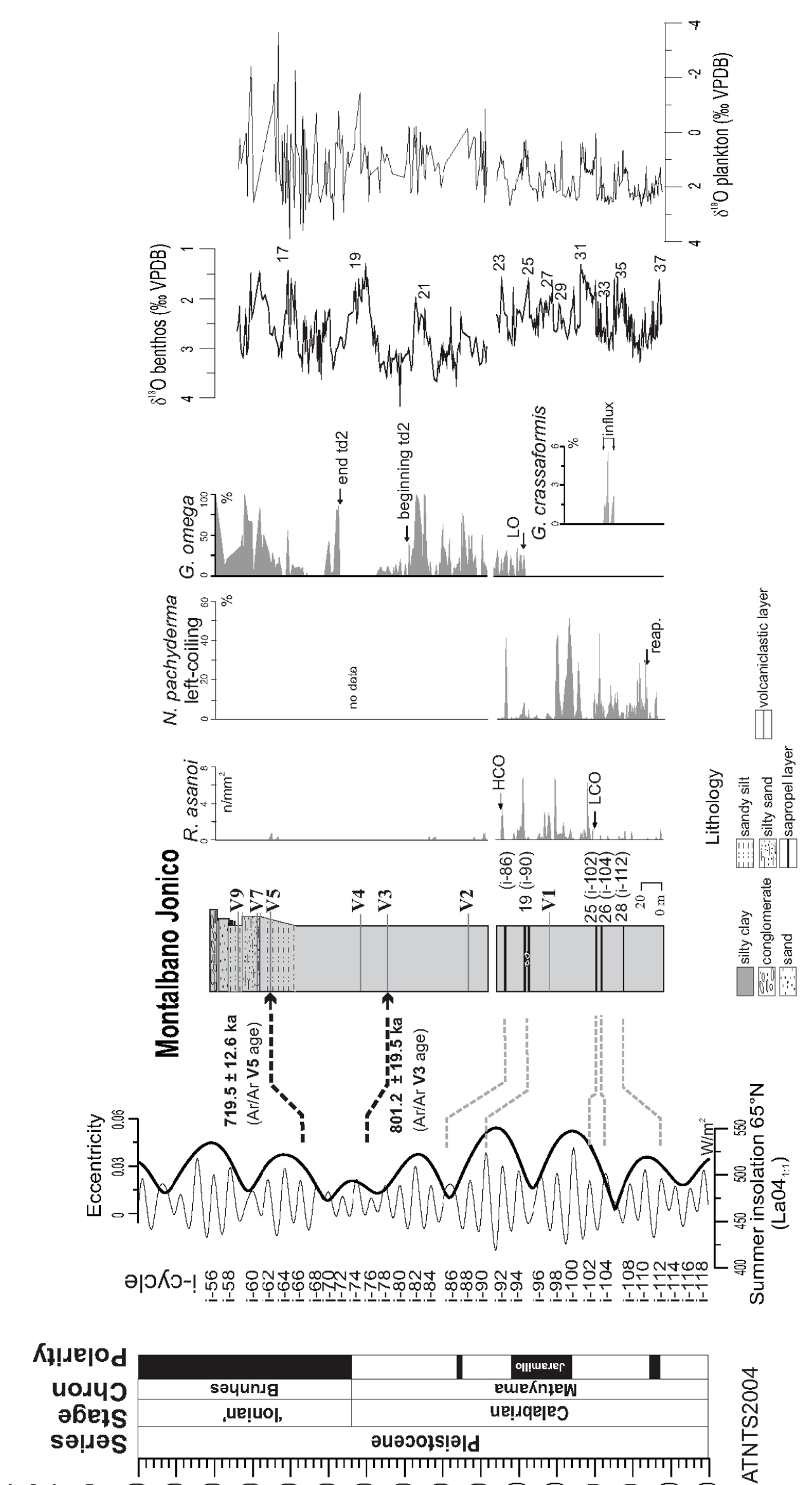

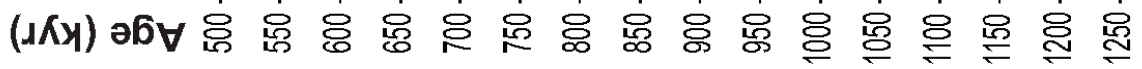

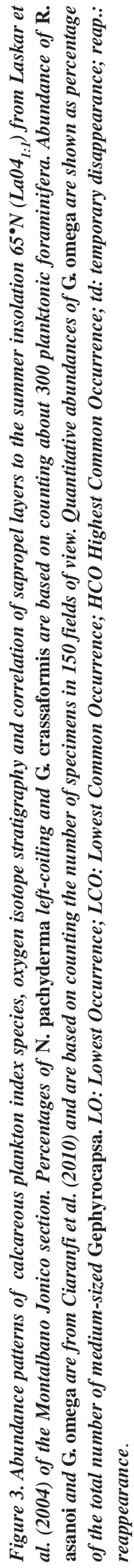


Table 2. List of the age estimation of Calabrian calcareous plankton biohorizons in selected reference sections. Depth in the section and correlation with oxygen isotope stratigraphy are indicated when available

\begin{tabular}{|c|c|c|c|c|c|}
\hline Bioevent & Section & Depth (m) & Age (Ma) & MIS & Reference \\
\hline LCO $N$. pachyderma left-coiling & $\begin{array}{l}\text { Vrica-Crotone section } \\
\text { ODP Site } 967 \text { (Mediterranean) } \\
\text { Eastern Mediterranean }\end{array}$ & $\begin{array}{l}127(\mathrm{~m}) \\
54.23(\mathrm{rmcd})\end{array}$ & $\begin{array}{l}1.799 \\
1.793 \\
1.79\end{array}$ & $\begin{array}{l}65-64 \\
65-64\end{array}$ & $\begin{array}{l}\text { Lourens et al. (1996) } \\
\text { Lourens et al. (1996) } \\
\text { Lourens et al. (2004) }\end{array}$ \\
\hline HO C. macintyrei & $\begin{array}{l}\text { Vrica-Crotone section } \\
\text { ODP Site } 967 \text { (Mediterranean) } \\
\text { Eastern Mediterranean } \\
\text { Equatorial Atlantic } \\
\text { Equatorial Pacific } \\
\text { DSDP Site } 607\end{array}$ & $\begin{array}{l}171(\mathrm{~m}) \\
67.67(\mathrm{mcd})\end{array}$ & $\begin{array}{l}1.671 \\
1.676( \pm 0.005) \\
1.664 \\
1.607 \\
1.60 \\
1.642\end{array}$ & $\begin{array}{l}58-57 \\
59-58 \\
\\
57\end{array}$ & $\begin{array}{l}\text { Lourens et al. (1996) } \\
\text { Lourens et al. (1998); Raffi (2002) } \\
\text { Raffi et al. (2006) } \\
\text { Raffi et al. (2006) } \\
\text { Raffi et al. (2006) } \\
\text { Raffi et al. (1993) recalibrated }\end{array}$ \\
\hline LO large Gephyrocapsa & $\begin{array}{l}\text { Vrica-Crotone section } \\
\text { ODP Site } 967 \text { (Mediterranean) } \\
\text { Eastern Mediterranean } \\
\text { Equatorial Atlantic } \\
\text { Equatorial Pacific (FCO) } \\
\text { DSDP Site } 607\end{array}$ & $\begin{array}{l}192(\mathrm{~m}) \\
64.43-64.6(\mathrm{mcd})\end{array}$ & $\begin{array}{l}1.608 \\
1.595( \pm 0.005) \\
1.617 \\
1.560 \\
1.46 \\
1.571-1.574\end{array}$ & $\begin{array}{l}55-56 \\
55-54\end{array}$ & $\begin{array}{l}\text { Lourens et al. (1996) } \\
\text { Lourens et al. (1998); Raffi (2002) } \\
\text { Raffi et al. (2006) } \\
\text { Raffi et al. (2006) } \\
\text { Raffi et al. (2006) } \\
\text { Raffi (2002) recalibrated }\end{array}$ \\
\hline $\begin{array}{l}\text { disappearance } \\
\text { N. pachyderma left-coiling }\end{array}$ & $\begin{array}{l}\text { Vrica-Crotone section } \\
\text { ODP Site 967 (Mediterranean) } \\
\text { ODP Site 969D (Mediterranean) } \\
\text { Eastern Mediterranean } \\
\text { DSDP Site } 607 \text { (North Atlantic) } \\
\end{array}$ & $\begin{array}{l}258(\mathrm{~m}) \\
44.38(\mathrm{rmcd}) \\
29.13(\mathrm{rmcd}) \\
\\
55.77(\mathrm{mcd})\end{array}$ & $\begin{array}{l}1.367 \\
1.370 \\
1.371 \\
1.37 \\
1.364 \\
\end{array}$ & $\begin{array}{r}44-43 \\
44-43 \\
\\
44-43 \\
\end{array}$ & $\begin{array}{l}\text { Lourens et al. (1996) } \\
\text { Lourens et al. (1998) } \\
\text { Lourens et al. (1998) } \\
\text { Lourens et al. (2004) } \\
\text { this study (data-set of Ruddimann et al.1986) }\end{array}$ \\
\hline HO H. sellii & $\begin{array}{l}\text { Vrica-Crotone section } \\
\text { ODP Site } 967 \text { (Mediterranean) } \\
\text { Eastern Mediterranean } \\
\text { Equatorial Pacific }\end{array}$ & $\begin{array}{l}295(\mathrm{~m}) \\
41.27(\mathrm{rmcd})\end{array}$ & $\begin{array}{l}1.24 \\
1.259 \\
1.256 \\
1.34\end{array}$ & $\begin{array}{l}37 \\
39-38\end{array}$ & $\begin{array}{l}\text { Lourens et al. (1996) } \\
\text { Lourens et al. (1998) } \\
\text { Raffi et al. (2006) } \\
\text { Raffi et al. (2006) }\end{array}$ \\
\hline HO large Gephyrocapsa & $\begin{array}{l}\text { Vrica-Crotone section } \\
\text { ODP Site } 967 \text { (Mediterranean) } \\
\text { Eastern Mediterranean } \\
\text { Equatorial Atlantic } \\
\text { Equatorial Pacific } \\
\text { DSDP Site } 607 \text { (North Atlantic) } \\
\end{array}$ & $\begin{array}{l}294(\mathrm{~m}) \\
41.22(\mathrm{rmcd}) \\
50.02(\mathrm{mcd})\end{array}$ & $\begin{array}{l}1.238 \\
1.257( \pm 0.003) \\
1.245 \\
1.255 \\
1.24 \\
1.227 \\
\end{array}$ & $\begin{array}{l}37 \\
38-37 \\
\\
37 \\
\end{array}$ & $\begin{array}{l}\text { Lourens et al. (1996) } \\
\text { Lourens et al. (1998); Raffi (2002) } \\
\text { Raffi et al. (2006) } \\
\text { Raffi et al. (2006) } \\
\text { Raffi et al. (2006) } \\
\text { Raffi et al. (1993) recalibrated }\end{array}$ \\
\hline beginning influx G. crassaformis & Montalbano Jonico section & $50.15(\mathrm{~m})$ & 1.148 & 34 & this study \\
\hline influx G. crassaformis & ODP Site 967 (Mediterranean) & 37.76 (rmcd) & 1.135 & & Lourens et al. (1998) \\
\hline end influx G. crassaformis & Montalbano Jonico section & $60.55(\mathrm{~m})$ & 1.119 & 34 & this study \\
\hline LCO $R$. asanoi & $\begin{array}{l}\text { Montalbano Jonico section } \\
\text { ODP Site } 964 \text { (Ionian Sea) } \\
\text { Core KC01B (Ionian Sea) } \\
\text { DSDP Site } 607 \text { (North Atlantic) } \\
\text { Eastern Mediterranean } \\
\text { Equatorial Atlantic }\end{array}$ & $\begin{array}{l}70.95(\mathrm{~m}) \\
37.35 \text { (rmcd) } \\
35.47 \text { (cpd) } \\
44.79 \text { (mcd) }\end{array}$ & $\begin{array}{l}1.086 \\
1.086 \\
1.081 \\
1.101 \\
1.078 \\
1.136\end{array}$ & $\begin{array}{l}31 \\
31 \\
31 \\
32\end{array}$ & $\begin{array}{l}\text { Ciaranfi et al. (2010) } \\
\text { Maiorano and Marino (2004) recalibrated } \\
\text { this study } \\
\text { Maiorano and Marino (2004) recalibrated } \\
\text { Lourens et al. (2004); Raffi et al. (2006) } \\
\text { Lourens et al. (2004); Raffi et al. (2006) }\end{array}$ \\
\hline $\begin{array}{l}\text { LO G. omega (= re-entrance medium } \\
\text { Gephyrocapsa) }\end{array}$ & $\begin{array}{l}\text { Montalbano Jonico section } \\
\text { ODP Site } 964 \text { (Ionian Sea) } \\
\text { Core KC01B (Ionian Sea) } \\
\text { Eastern Mediterranean } \\
\text { Equatorial Atlantic } \\
\text { Equatorial Pacific } \\
\text { DSDP Site } 607 \text { (North Atlantic) }\end{array}$ & $\begin{array}{l}138.15(\mathrm{~m}) \\
34.31(\mathrm{rmcd}) \\
32.62(\mathrm{cpd}) \\
\\
41.32-40.74(\mathrm{mcd})\end{array}$ & $\begin{array}{l}0.954 \\
0.957 \\
0.962 \\
0.956-0.985 \\
1.007 \\
1.040 \\
1.018-1.004\end{array}$ & $\begin{array}{l}25 \\
25 \\
26-25\end{array}$ & $\begin{array}{l}\text { Ciaranfi et al. (2010) } \\
\text { Maiorano and Marino (2004) recalibrated } \\
\text { Castradori (1992) recalibrated } \\
\text { Raffi et al. (2006) } \\
\text { Raffi et al. (2006) } \\
\text { Raffi et al. (2006) } \\
\text { Raffi (2002) recalibrated }\end{array}$ \\
\hline HCO R. asanoi & $\begin{array}{l}\text { Montalbano Jonico section } \\
\text { ODP Site } 964 \text { (Ionian Sea) } \\
\text { Core KC01B (Ionian Sea) } \\
\text { DSDP Site } 607 \text { (North Atlantic) } \\
\text { Eastern Mediterranean } \\
\text { Equatorial Atlantic } \\
\end{array}$ & $\begin{array}{l}162.85(\mathrm{~m}) \\
32.93(\mathrm{rmcd}) \\
31.335(\mathrm{cpd}) \\
36.23(\mathrm{mcd})\end{array}$ & $\begin{array}{l}0.908 \\
0.902 \\
0.902 \\
0.906 \\
0.901 \\
0.905\end{array}$ & $\begin{array}{l}23 \\
23 \\
23 \\
23\end{array}$ & $\begin{array}{l}\text { Ciaranfi et al. (2010) } \\
\text { Maiorano and Marino (2004) recalibrated } \\
\text { this study } \\
\text { Maiorano and Marino (2004) recalibrated } \\
\text { Raffi et al. (2006) } \\
\text { Raffi et al. (2006) }\end{array}$ \\
\hline beginning temp. disap. G. omega & $\begin{array}{l}\text { Montalbano Jonico section } \\
\text { ODP Site } 964 \text { (Ionian Sea) } \\
\text { Core KC01B (Ionian Sea) } \\
\text { DSDP Site } 607 \text { (North Atlantic) }\end{array}$ & $\begin{array}{l}82.65(\mathrm{~m}) \\
30.82(\mathrm{rmcd}) \\
29.51(\mathrm{cpd}) \\
33.31(\mathrm{mcd})\end{array}$ & $\begin{array}{l}0.828 \\
0.819 \\
0.820 \\
0.821\end{array}$ & $\begin{array}{l}21-20 \\
21-20 \\
21-20 \\
21-20\end{array}$ & $\begin{array}{l}\text { this study } \\
\text { this study } \\
\text { this study (data-set of Castradori, 1992) } \\
\text { Maiorano and Marino (2004) recalibrated }\end{array}$ \\
\hline end temp. disap. G. omega & $\begin{array}{l}\text { Montalbano Jonico section } \\
\text { ODP Site } 964 \text { (Ionian Sea) } \\
\text { Core KC01B (Ionian Sea) } \\
\text { DSDP Site } 607 \text { (North Atlantic) }\end{array}$ & $\begin{array}{l}155.45(\mathrm{~m}) \\
29.885(\mathrm{rmcd}) \\
28.505(\mathrm{cpd}) \\
31.64(\mathrm{mcd})\end{array}$ & $\begin{array}{l}0.771 \\
0.782 \\
0.774 \\
0.781\end{array}$ & $\begin{array}{l}19-18 \\
19-18 \\
19-18 \\
19\end{array}$ & $\begin{array}{l}\text { Ciaranfi et al. (2010) } \\
\text { this study } \\
\text { this study (data-set of Castradori, 1992) } \\
\text { Maiorano and Marino (2004) recalibrated }\end{array}$ \\
\hline
\end{tabular}




\begin{tabular}{|c|c|c|c|c|c|c|}
\hline Sample \# & Material & $\mathrm{K} / \mathrm{Ca}$ & $\begin{array}{l}\text { Total fusion } \\
\text { Age (ka) } \pm 2\end{array}$ & N & MSWD & $\begin{array}{l}\text { Weighted Mean } \\
\text { Age } \pm 2\end{array}$ \\
\hline V3 & sanidine & 32.89 & $803.5 \pm 22.6$ & 11 of 11 & 0.55 & $801.2 \pm 19.5$ \\
\hline
\end{tabular}

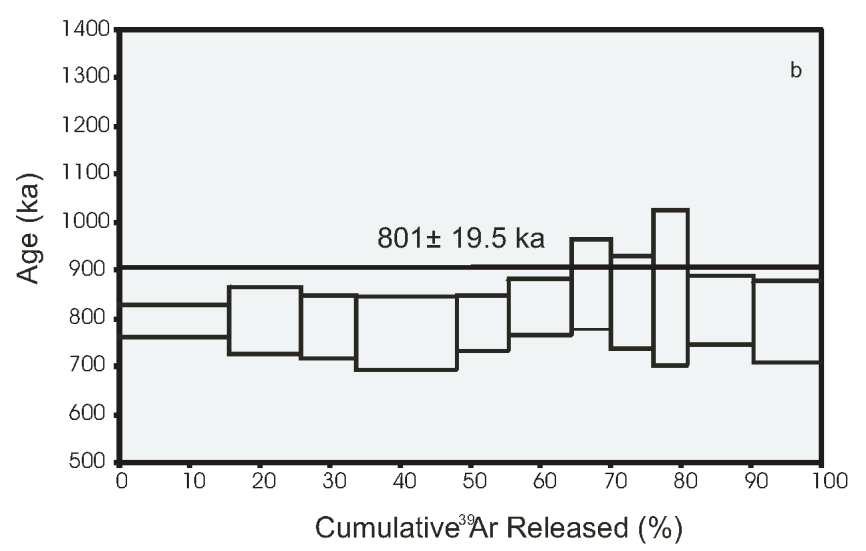

Figure 4. Summary of ${ }^{40} \mathrm{Ar} /{ }^{39} \mathrm{Ar}$ incremental heating results for the volcaniclastic layer $\mathrm{V3}(\mathrm{a}) .{ }^{40} \mathrm{Ar} /{ }^{39} \mathrm{Ar}$ age spectra from the $\mathrm{V} 3$ volcaniclastic layer (b).

below V5, whose age was determined at 719.5 $\pm 12.6 \mathrm{ka}$ (Ciaranfi et al., 2010). At around the Lower - Middle Pleistocene boundary interval several volcanic sources were active in Italy (Ventotene-Santo Stefano

islands, Vulture volcano, Sabatini volcanoes, Aeolian seamounts, Linosa and Ustica islands - Peccerillo, 2005 and references therein). Unfortunately, the absence of chemical data on the glass composition makes difficult any inference on the source of volcaniclastic layer V3. In fact, a tephra layer of comparable age ( $802 \pm 8 \mathrm{ka})$, possibly emplaced from an ancient and poorly known activity of Sabatini volcanoes, was found in several drill-holes in the Tiber River coastal alluvial plain (Karner et al., 2001; Florindo et al., 2007). The former authors, however, document a low size pyroclastic fall event for the Tiber River tephra layer, which is not likely compatible with a dispersal from Sabatini volcanoes reaching the Montalbano area.

As discussed in Ciaranfi et al. (2010), the astronomical tuning of the Montalbano Jonico section (Figures 56) was achieved using a 3 ky time lag between the midpoints of each individual sapropel and their correlative precession minima, in the lower part of the section, and the visual comparison of the $\delta^{18} \mathrm{O}$ pattern with the record available at the Mediterranean ODP Site 975, and the ${ }^{39} \mathrm{Ar} /{ }^{40} \mathrm{Ar}$ age of V5 layer, in the upper part of the section. Slight modifications included in this paper follow the new ${ }^{39} \mathrm{Ar} /{ }^{40} \mathrm{Ar}$ age of V3 layer dated at 801.2 \pm $19.5 \mathrm{ka}$. The astronomical calibration of the Montalbano Jonico section shows that it covers an interval from 1.240 Ma to 0.645 Ma (Figure 6) and provides accurate ages for the biostratigraphic data.

\section{Astronomical Age of Calabrian Biostratigraphic data}

The chronology of the lower Calabrian biostratigraphic data, widely discussed in several papers (Raffi, 2002; Lourens et al., 2004; Raffi et al., 2006), is summarized in Figure 7 and Table 2. In the present paper we discuss only the new data collected in the Montalbano Jonico section and correlated records in the sedimentary interval corresponding to the upper part of the Calabrian Stage. In addition, we provide a new chronology of bioevents at DSDP Site 607 for the entire Calabrian interval according to the updated age model of Lisiecki and Raymo (2005).

\section{Reappearance of $\mathrm{N}$. pachyderma left-coiling}

The pattern of $N$. pachyderma left-coiling offers multiple biohorizons through the whole Calabrian Stage as can be observed in Figure 8 . The taxon has a first abundance increase associated with MIS 64 followed by several abundance peaks during glacial marine isotope stages from MIS 64 to 44 (Figure 8), as previously observed by Lourens et al. $(1996 ; 1998)$. Abundance peaks are absent through

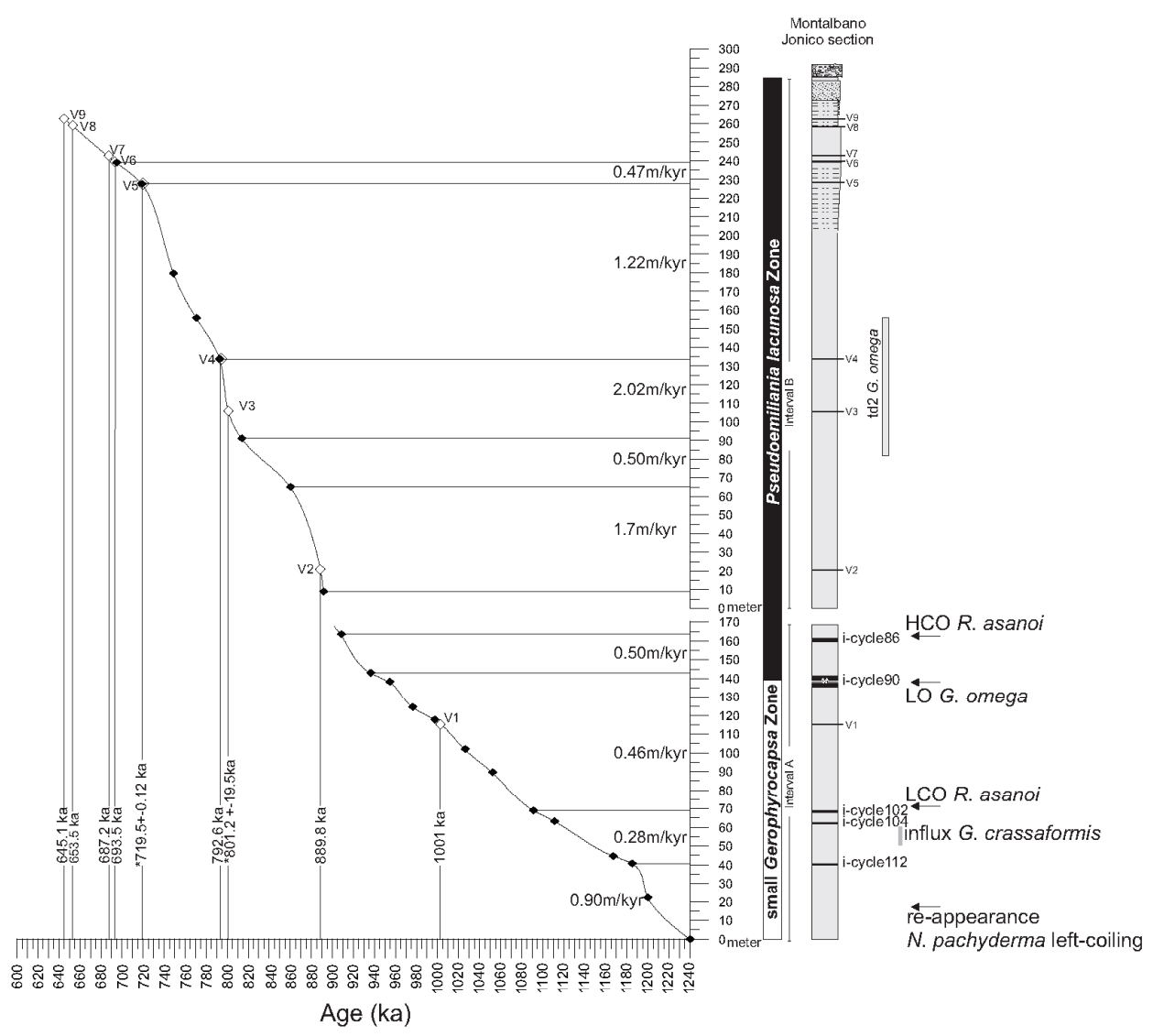

Figure 5. Age-depth profile of Montalbano Jonico composite section. The black diamonds represent the tie-points while the white ones are the position of the volcaniclastic layers. For sediment symbols and abbreviations refer to Figure 3. 


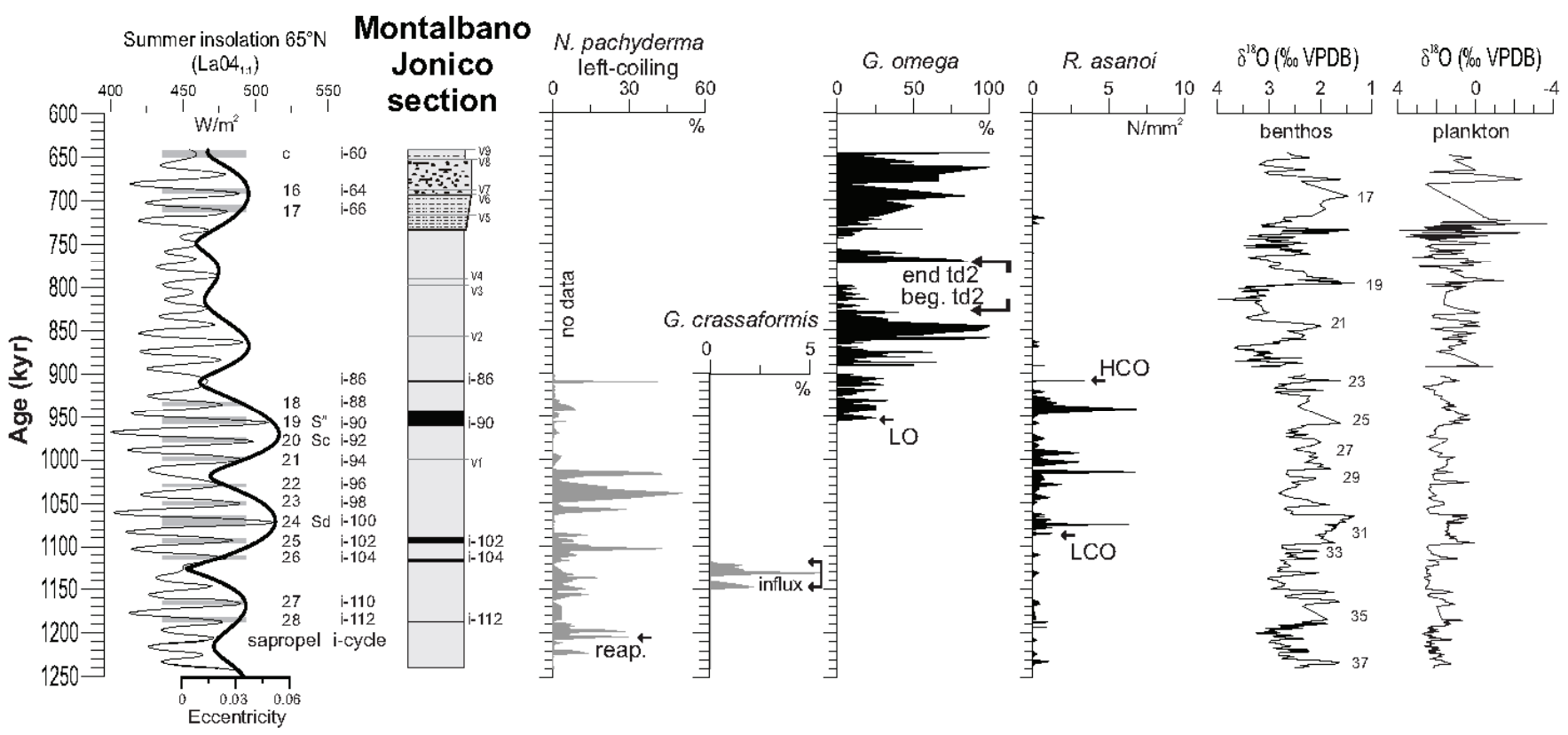

Figure 6. Abundance patterns of calcareous plankton index species and oxygen isotope stratigraphy of Montalbano Jonico section plotted versus age based on astronomical calibration of Ciaranfi et al. (2010) and this study. Position of biohorizons are also traced for comparison on the oxygen isotope Mediterranean stacked record of Lourens (2004) according to Mediterranean biochrology in Lourens et al. (1998), Lourens et al. (2004), Maiorano and Marino (2004), Raffi et al. (2006), Lourens et al. (2006), Ciaranfi et al. (2010). lG: large Gephyrocapsa; Npl: N. pachyderma left-coiling; Gc: G. crassaformis; Ra: R. asanoi; Go: G. omega. For sediment symbols and abbreviations see Figure 3.

MIS 42-38 and i-cycles 132-114 (interval of temporary disappearance in Figure 8) and re-occur (reappearance event) from MIS 36 upwards. The reappearance of $N$. pachyderma left-coiling at Montalbano Jonico section has an astronomical age of 1.206 Ma, in good agreement with that found in other Mediterranean areas (ODP Sites 967 and 969 at 1.209 Ma and 1.203 Ma respectively) (Table 2). The position of this bioevent relative to sapropel 28 (i-112) at Montalbano Jonico and Site 967 is straightforward (Figure 8) and further confirms the astronomical tuning of the section. A slightly older age for the event (1.220 Ma) is known in the Vrica-Crotone section (Lourens et al., 1996). The interval of temporary disappearance of the taxon is not just a Mediterranean feature, as revealed by the Atlantic DSDP Site 607 (Figure 8). Based on the abundance pattern of $N$. pachyderma left-coiling of Ruddiman et al. (1989) and on the time series of Site 607 (Lisiecki and Raymo, 2005), we provide the position and age of disappearance and reappearance of N. pachyderma left-coiling at the North Atlantic site (Figure 8; Table 2). An age of 1.207 Ma for the reappearance event recorded in the North Atlantic site, is highly consistent with the age estimate of the event in the Montalbano Jonico section.

\section{Influx of $\mathrm{G}$. crassaformis}

Various influxes of G. crassaformis have been identified in the lower part of the Calabrian Stage (Lourens et al., 1998) in the Mediterranean area, mostly in deep-sea sections (Figure 8), although quantitative patterns are not available. Here we report quantitative distribution of the influx of the species recorded in the Montalbano Jonico section which is the only record exposed on land known so far. The short influx of G. crassaformis extends from 1.148 Ma to 1.119 Ma, within MIS 34, in agreement with the results obtained by Lourens et al. (1998) for the ODP Mediterranean Sites 967 and 969 (at $1.135 \mathrm{Ma}$ and $1.140 \mathrm{Ma}$, respectively). The high sedimentation rate of the section (Figure 5) and the high resolution sampling reveal the temporal extent of the influx (about $30 \mathrm{ky}$ ) and a more accurate calibration of the event with respect to previous data.

\section{Highest Occurrence of large Gephyrocapsa (> $5.5 \mu \mathrm{m})$}

The absence of large gephyrocapsids ( $>5.5 \mu \mathrm{m}$ ) from the bottom of the Montalbano Jonico section is unequivocal, thus indicating a stratigraphic interval younger in age than their disappearance. It is also in agreement with the calibration of the base of the Montalbano Jonico section at 1.240 Ma. The absence of large gephyrocapsids is consistent with the calibration of the HO event at Site 967 (Figure 8; Table 2) where it has an age of $1.257 \mathrm{Ma}$ (Lourens et al., 1998) and is associated with MIS 38/37 (Raffi, 2002). The HO of large gephyrocapsids is considered a reliable event, isochronous in midand low-latitude areas (Raffi et al., 1993, 2006; Raffi, 2002). In the Eastern Mediterranean deep-sea sections it has been dated at 1.245 Ma (Lourens et al., 2004; Raffi et al., 2006), while in the Atlantic and Pacific Ocean it has an age of 1.255 Ma and 1.24 Ma, respectively. A slightly younger age (1.227 Ma) is recorded at the Atlantic Site 607 (Table 2) and at the Vrica-Crotone section (1.238 Ma, Table 2).

\section{Lowest Common Occurrence and Highest}

\section{Common Occurrence of $\mathrm{R}$. asanoi}

The LCO and HCO of $R$. asanoi have been recorded previously in the Montalbano Jonico section (Maiorano et al., 2004; Ciaranfi et al., 2010). Calibrations and the reliability of these bioevents in Mediterranean and oceanic areas have been discussed in Maiorano and Marino (2004), Raffi et al. (2006) and Ciaranfi et al. (2010). In Core KC01B new data (with sampling resolution of 1 sample per 


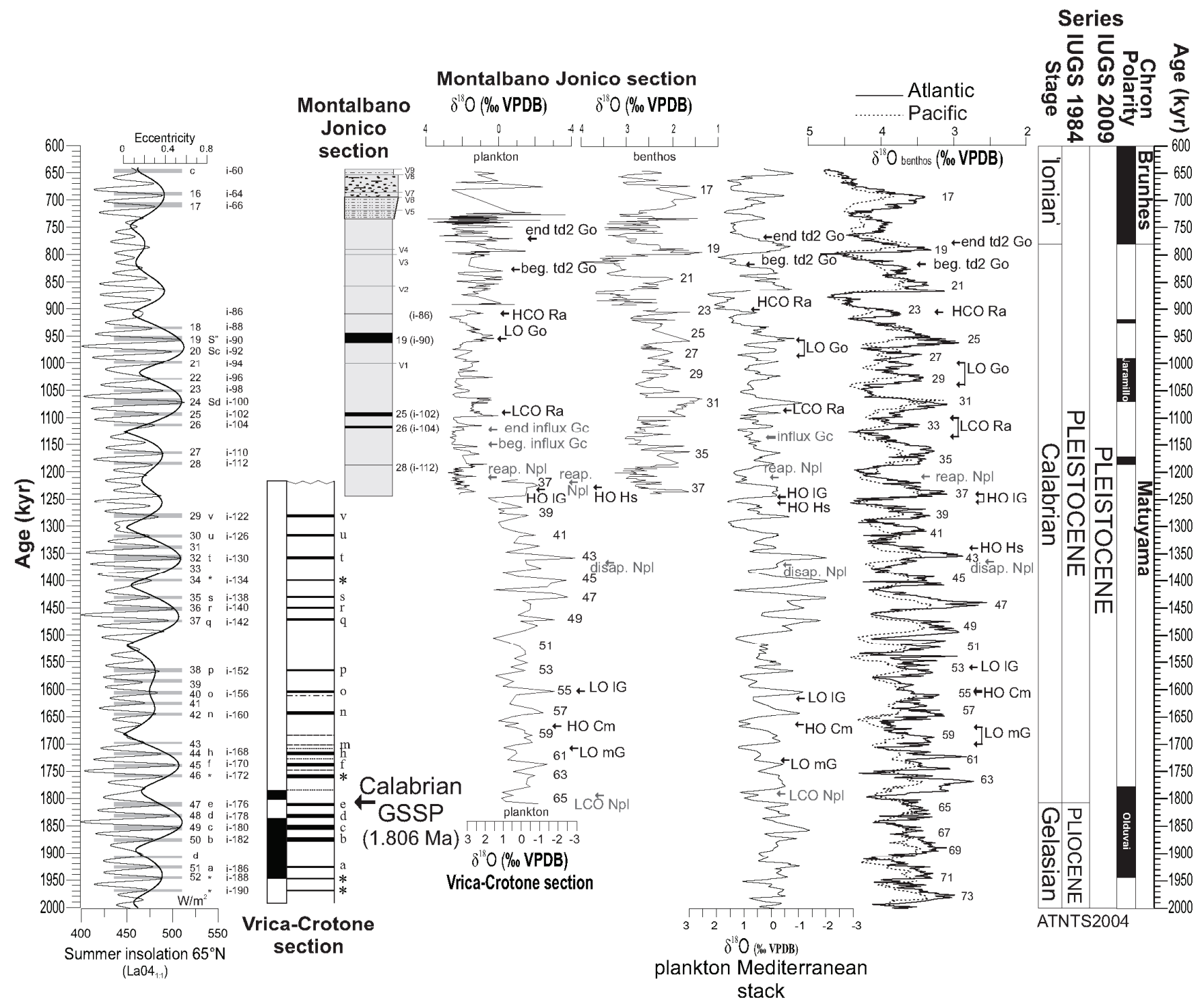

Figure 7. Oxygen isotope chronologies of the astronomically tuned Vrica-Crotone and Montalbano Jonico sections recovering the entire Calabrian Stage. Position of biohorizons are also traced for comparison on the oxygen isotope Mediterranean stacked record of Lourens (2004) and on Pacific (Mix et al., 1995a,b; Shackleton et al., 1995) and Atlantic (Bickert et al., 1997) $\delta^{18} \mathrm{O}$ benthic records according to biochrology in Lourens et al. (1998), Raffi (2002), Lourens et al. (2004), Maiorano and Marino (2004), Raffi et al. (2006), Lourens et al. (2006), Ciaranfi et al. (2010) as reported in Table 2. Summer insolation $65^{\circ} \mathrm{N}$ (La04 1:1) from Laskar et al. (2004). Npl: N. pachyderma leftcoiling; $m G$ : medium Gephyrocapsa; $C m$ : C. macintyrei; $l G$ : large Gephyrocapsa; Hs: H. sellii; Gc: G. crassaformis; Ra: R. asanoi; Go: G. omega. LO: Lowest Occurrence; HO: Highest Occurrence; LCO: Lowest Common Occurrence; HCO: Highest Common Occurrence; reap.: reappearance; disap.: disappearance; td: temporary disappearance. For sediment symbols see Figures 2-3.

2-4 ky) are presented on the distribution pattern of calcareous nannofossil $R$. asanoi (Figure 9). This species, in fact, was not previously recorded in this section. The results are plotted against the astronomical age model of the core (Lourens, 2004). The data-set is compared with the temporal distribution at the Montalbano Jonico section, and with the previous results of Maiorano and Marino (2004) at ODP Site 964 and DSDP Site 607 based on the adopted age models. Both the LCO and HCO of $R$. asanoi display a high degree of correlation between the Montalbano Jonico section and the other records, mainly in the Mediterranean area, as it is clear from Figure 9 and Table 2. A slightly older age of the LCO event is obtained at DSDP Site 607 (Table 2), possibly due to lower sampling resolution in this interval (Figure 9); on the other hand, a consistent discrepancy is observed with the equatorial Atlantic calibration (Table 2). As discussed in Raffi (2002) and Maiorano and Marino (2004), different calibrations of this event may derive from different taxonomic concepts or from the discontinuous occurrences of the species in the lower part of its range. The age of $0.908 \mathrm{Ma}$ detected at the Montalbano Jonico section for the HCO of $R$. asanoi is remarkably in accordance with both Mediterranean and oceanic records (Figures 7, 9; Table 2).

\section{Lowest Occurrence and temporary disappearance of $\mathrm{G}$. omega}

The LO of G. omega (= re-entrance medium Gephyrocapsa) in the Montalbano Jonico section has been dated at $0.954 \mathrm{Ma}$ (Ciaranfi 

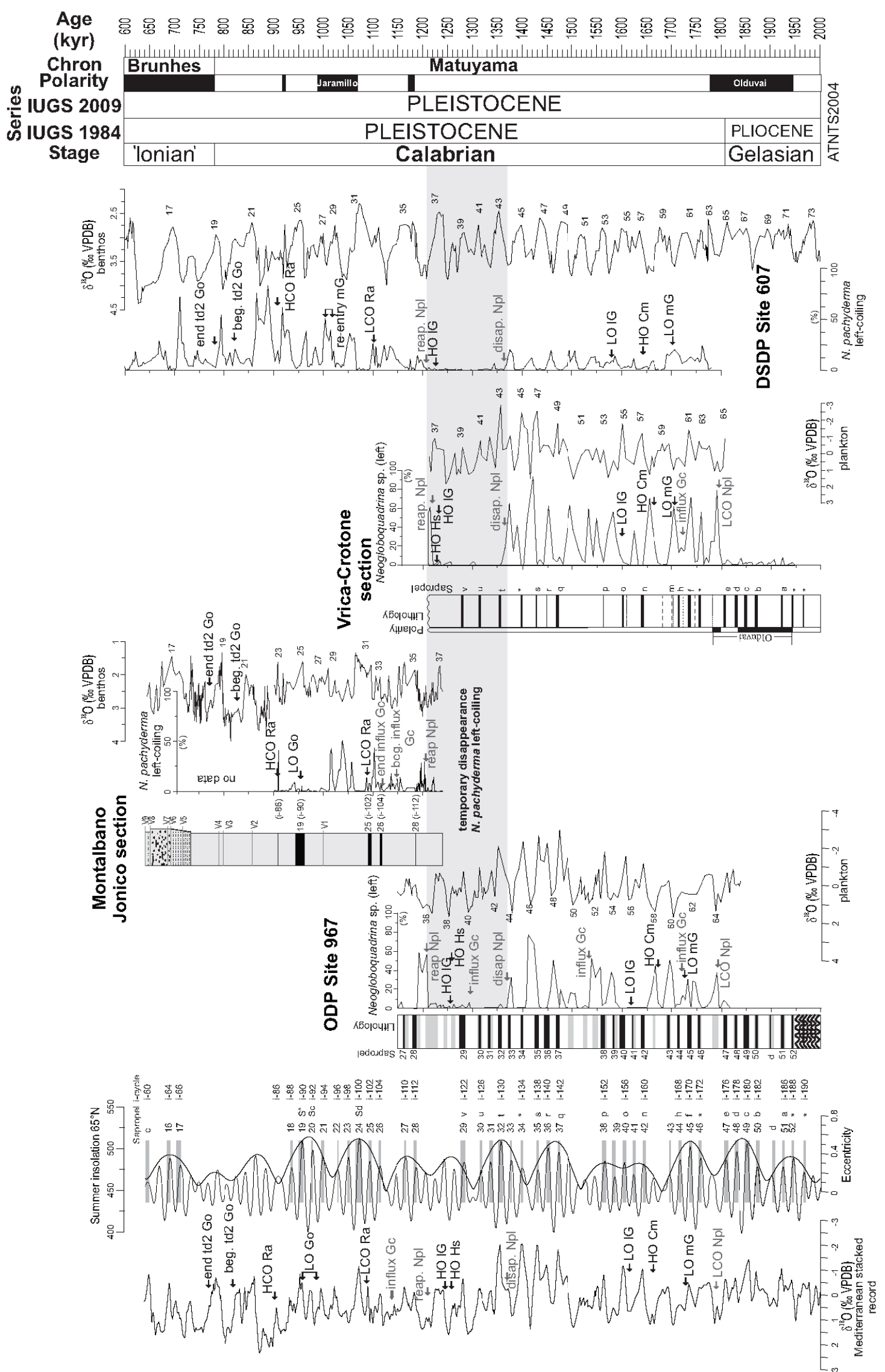

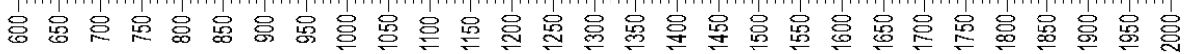




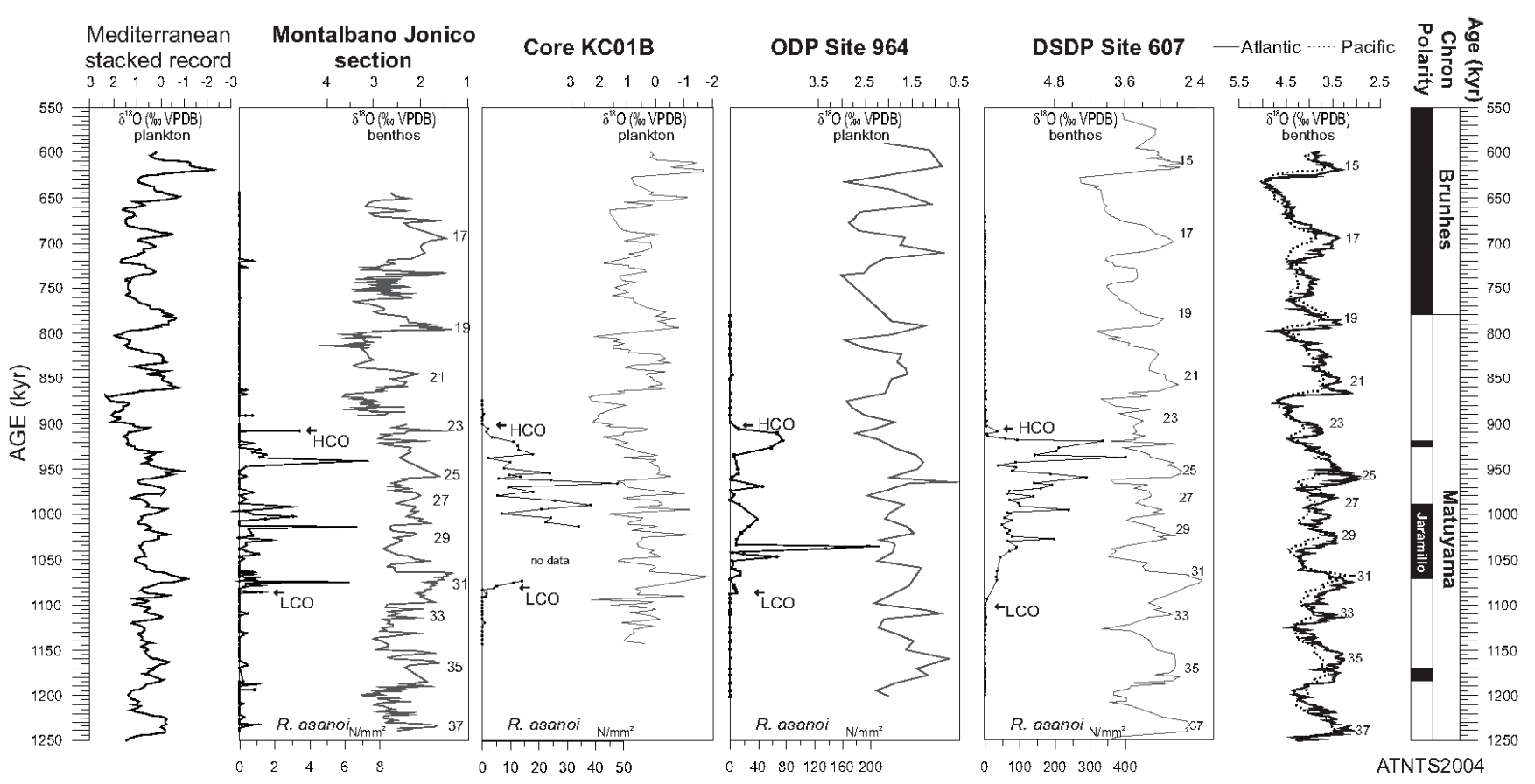

Figure 9. Temporal distribution of R. asanoi and oxygen isotope time series at Montalbano Jonico section and Core KC01B, ODP Site 964 and DSDP Site 607. Numerical abundance patterns are from Ciaranfi et al. (2010) at Montalbano Jonico section, from this study at Core KC01B and from Maiorano and Marino (2004) at ODP Site 964 and DSDP Site 607. Abundances are plotted versus age according to oxygen isotope time series of Ciaranfi et al. (2010) and this study at Montalbano Jonico, Lourens (2004) at Core KC01B and 964 and Lisiecki and Raymo (2005) at Site 607. Mediterranean $\delta^{18}$ O planktonic stacked record of Lourens (2004), Pacific (Mix et al., 1995a,b; Shackleton et al., 1995) and Atlantic (Bickert et al., 1997) $\delta^{18} \mathrm{O}$ benthic records are also shown for comparison. For abbreviations refer to Figure 7.

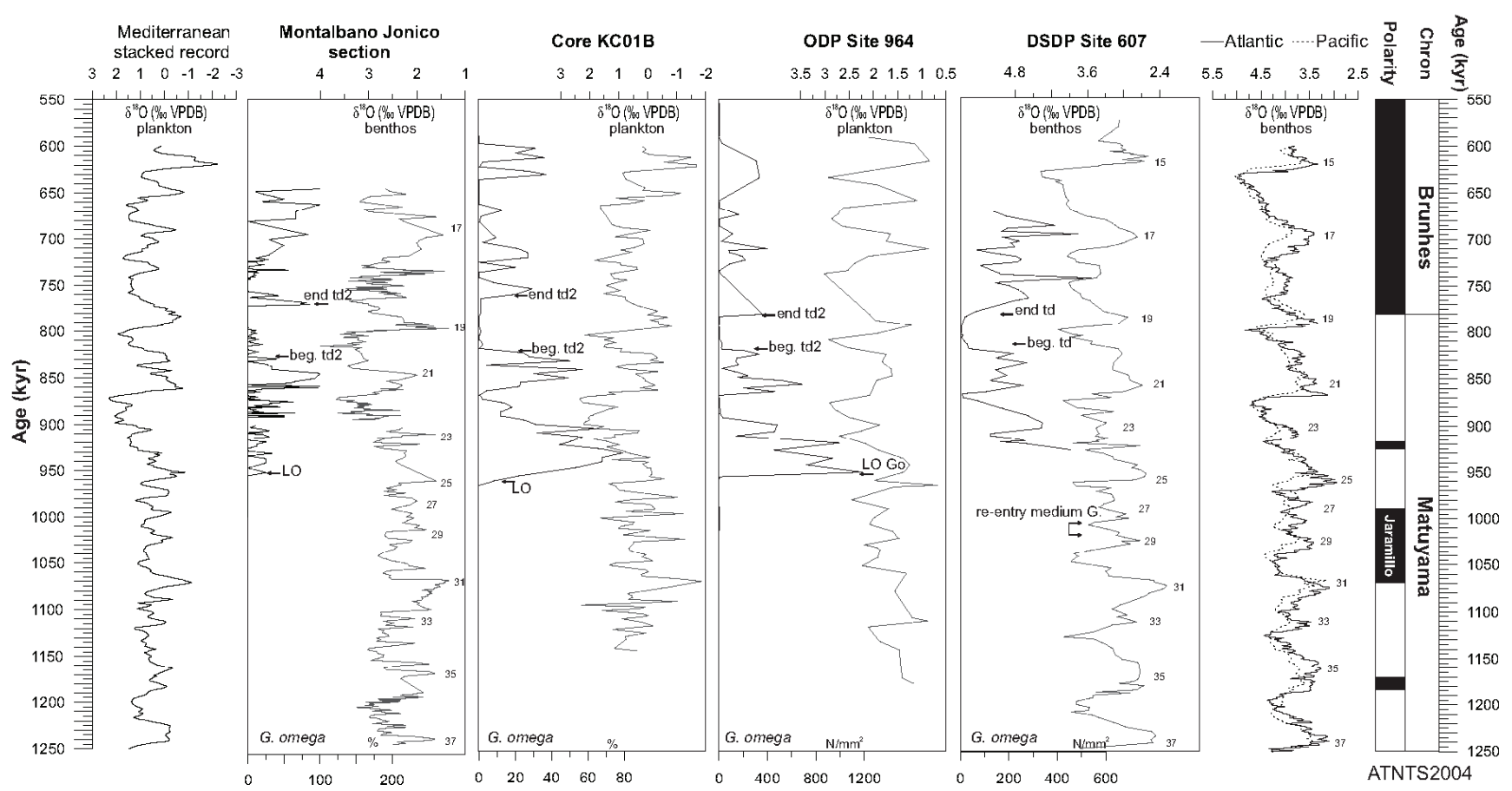

Figure 10. Temporal distribution of G. omega and oxygen isotope stratigraphy at Montalbano Jonico on-land section and Core KC01B, ODP Site 964 and DSDP Site 607. Numerical abundance patterns are from Ciaranfi et al. (2010) at Montalbano Jonico section, Castradori (1992) at Core KC01B and Maiorano and Marino (2004) at ODP Site 964 and DSDP Site 607. Abundances are plotted versus age according to oxygen isotope time series of Ciaranfi et al. (2010) and this study at Montalbano Jonico, Lourens (2004) at cores KC01B and 964 and Lisiecki and Raymo (2005) at Site 607. 
et al., 2010) and is in accordance with the considered Mediterranean records (Figure 10). However, the event is widely documented both in Mediterranean and oceanic records as a diachronous event (Raffi et al., 1993, 2006; Raffi, 2002) as also detectable from Figure 7. An interval of temporary disappearance of G. omega occurs in the Montalbano Jonico section (Ciaranfi et al., 2010) and is correlatable to td 2 of Maiorano and Marino (2004). The beginning and end of the temporary disappearance of $G$. omega have been dated at 0.828 and $0.771 \mathrm{Ma}$, respectively (recalibrated from Ciaranfi et al., 2010). The interval of temporary disappearance of G. omega is still poorly documented in deep-sea sections. Reconsideration of the distribution pattern of G. omega (against the updated age model at Core KC01B, Site 964 and Site 607), highlights a good correlation of the interval of temporary disappearance among the selected sections (Figure 10, Table 2), spanning from MIS 21-20 to MIS 19-18. It is noteworthy that the end of the temporary disappearance of G. omega represents the only calcareous plankton event which may approximate the Matuyama/Brunhes reversal in the marine records (Figure 7).

\section{The 'Ionian' Stage: Middle Pleistocene}

The Early-Middle Pleistocene Subseries boundary and the 'Ionian' Stage still lack a formal ratification. The name Ionian as the Stage representing the Middle Pleistocene was first introduced by Cita and Castradori (1995) and Van Couvering (1995) and its present use basically follows Cita et al. (2006) and Cita et al. (2008). According

\section{Montalbano Jonico}

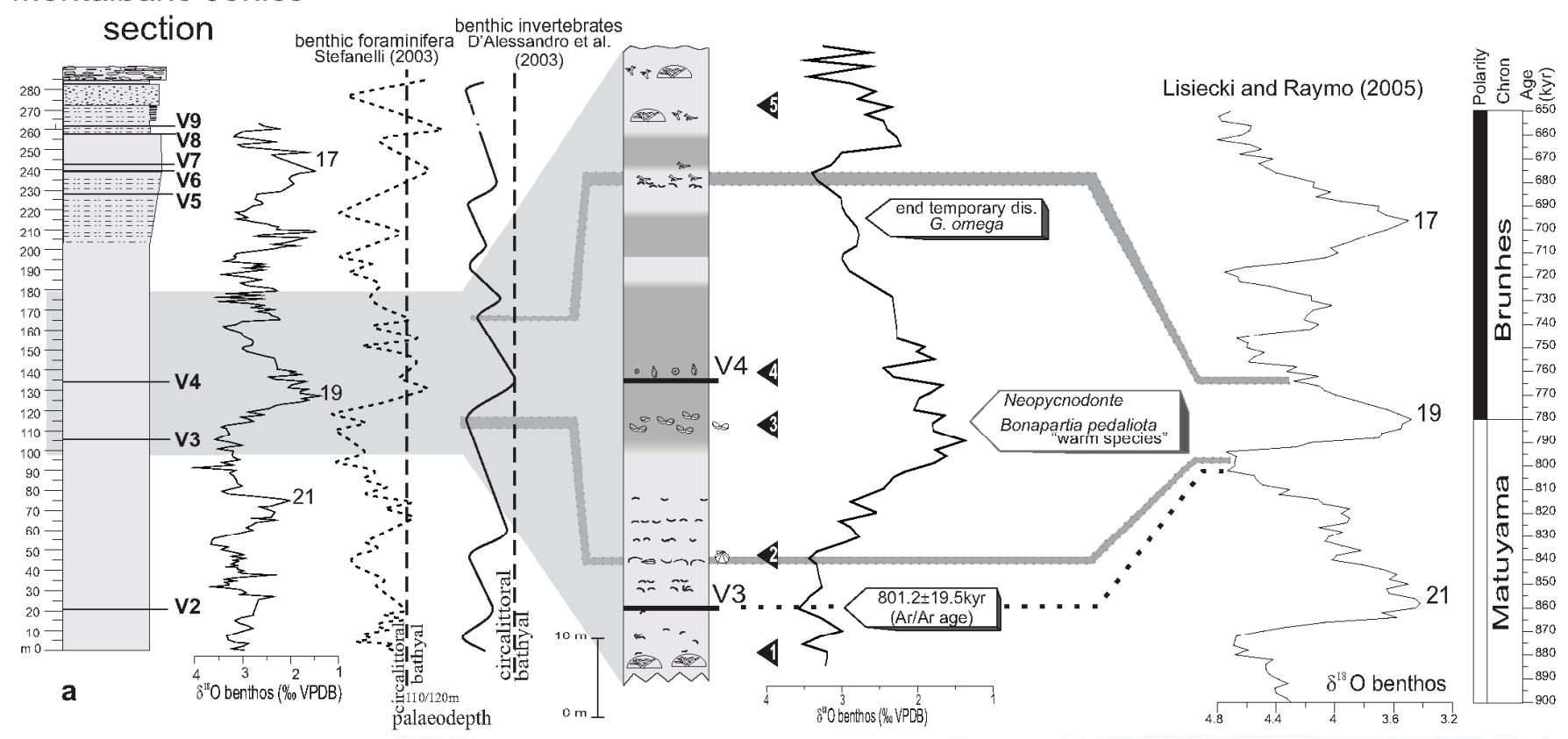

b

\begin{tabular}{|c|c|}
\hline & Light grey silty clay \\
\hline & Dark grey silty clay \\
\hline A & Nassarius \\
\hline$\infty \infty$ & Neopycnodonte cochlear \\
\hline$\odot$ & Discospirina \\
\hline 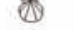 & Aequipecten opercularis \\
\hline ar & Ditrupa \\
\hline & Bryozoans \\
\hline - & Disarticulated valves \\
\hline & $\begin{array}{l}\text { Ditrupal } \\
\text { rect bryozoans }\end{array}$ \\
\hline & $\begin{array}{l}\text { opercularisl } \\
\text { Sarvicardium }\end{array}$ \\
\hline & $\begin{array}{l}N . \text { cochlear } \\
\text { naximum flooding) }\end{array}$ \\
\hline 4 & iscospirina-Nassarius \\
\hline $5 \mathrm{r}$ & eporiform bryozoans \\
\hline
\end{tabular}

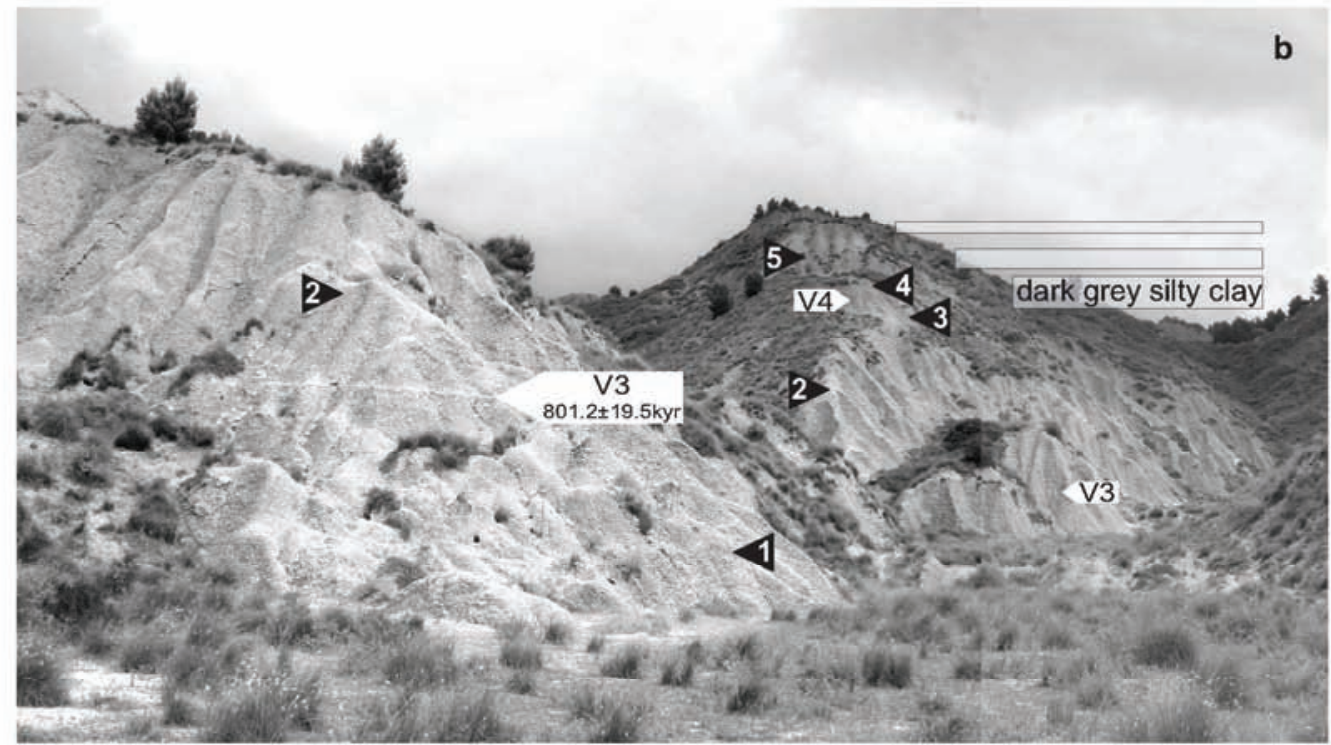

Figure 11. Oxygen isotope record and paleobathymetric changes from Montalbano Jonico section and correlation with oxygen isotope stratigraphy of Lisiecki and Raymo (2005) through MIS 19 (a). Radiometric and biostratigraphic constraints (Ciaranfi et al., 2010 and this study) and diagnostic fossil paleocommunity (D'Alessandro et al., 2003; Girone and Varola, 2001) are indicated. (b) Detail of lithological sequence of Montalbano Jonico section through the interval including MIS 19, with positions of characteristic marker layers. 
to the "Working Group of the Early-Middle Pleistocene Boundary" Subcommission for Quaternary Stratigraphy (32nd International Geological Congress in Florence in 2004), the Early-Middle Pleistocene boundary should be defined in a marine section exposed on land at a point "close" to the Matuyama/Brunhes reversal (Head et al., 2008b). Several opinions (Richmond, 1996; Pillans, 2003; Head and Gibbard, 2005) concur in considering the Matuyama-Brunhes paleomagnetic Chron boundary as the primary chronostratigraphic guide for establishing the Early-Middle Pleistocene boundary, although it is only one of multiple criteria that will be used for local, global and regional correlation of the boundary (Head et al., 2008b). At present, the selection of a suitable section for the GSSP of EarlyMiddle Pleistocene boundary has not been made.

The age of Matuyama-Brunhes reversal is known to have no unanimous agreement; it has been recently dated at $c a$. 789 ka by Quidelleur et al. (2003), ca. 774 ka by Channell et al. (2004), ca. 776 ka by Coe et al. (2004) and Singer et al. (2008). An age of 781 ka has been estimated in the astronomical-tuned time scale (Lourens et al., 2004). The Matuyama-Brunhes boundary is known to be closely correlated to MIS 19 (Shackleton et al., 1990; Lisiecki and Raymo, 2005). With regards to the marine isotope substages associated with MIS $19(19.3,19.2,19.1)$ recognized in few $\delta^{18}$ O planktonic records, the Matuyama-Brunhes reversal has been recorded between marine isotope substages 19.3 and 19.2 (Bassinot et al., 1994), between marine isotope substages 19.3 and 18.4 (Channel et al., 2004), or in the middle part of MIS 19, between marine isotope substages 19.3 and 19.1 (Capraro et al., 2005). The lack of magnetostratigraphic record at Montalbano Jonico section does not help to improve the correlation between Matuyama/Brunhes reversal and MIS 19. Furthermore, the substage subdivision of MIS 19 is rarely recognized in the planktonic and benthic $\delta^{18} \mathrm{O}$ reference records and it is not proposed at the Montalbano Jonico section. On the other hand, the shift from heavier to lighter $\delta^{18} \mathrm{O}$ values, associated with the onset of MIS 19, is clearly displayed in the benthic $\delta^{18} \mathrm{O}$ record at Montalbano Jonico section (Figure 11) and it may represent an alternative and suitable horizon for the definition of the GSSP of the 'Ionian' Stage. Variations in $\delta^{18} \mathrm{O}$ mainly reflect astronomically controlled glacial cyclicity and are a powerful tool for global, high-resolution chronostratigraphic correlation. Although Marine Isotope Stage boundaries are not formally defined, a benthic $\delta^{18} \mathrm{O}$ "type section" obtained from 57 globally distributed records, the so-called stack record, is available for the last 5.3 Ma (Lisiecki and Raymo, 2005) with the aim to provide a common timescale of the Marine Isotope Stages. The isotopic signals are considered acceptable for the definition of boundary stratotypes (Remane et al., 1996) and, in fact, this practice has been recently adopted for the definition of the GSSP of the Serravallian Stage (Hilgen et al., 2009).

The onset of MIS19 in the Montalbano Jonico section is very close to the radiometrically dated volcaniclastic layer V3 (801.2 \pm $19.5 \mathrm{ka}$ ) (Figure 11a) and occurs between 799 and $795 \mathrm{ka}$. This tuning is consistent with the calibration of MIS 19/20 boundary at $790 \mathrm{ka}$ (Lisiecki and Raymo, 2005). In terms of calcareous nannofossils, MIS 19 in the Montalbano Jonico section falls between the beginning and end of the temporary disappearance interval of G. omega, dated at $0.828 \mathrm{Ma}$ and $0.771 \mathrm{Ma}$, respectively. The sedimentary interval containing MIS 19 is represented by outer shelf deposits recording cyclic sea level changes (Figure 11a). A maximum flooding surface, highlighted by the occurrence of Neopycnodonte paleocommunity (D'Alessandro et al., 2003), has been documented in considerable detail and correlates with MIS 19. It is also accompanied by the occurrence of the mesopelagic species Bonapartia pedaliota (Girone and Varola, 2001), a tropical-sutropical Atlantic teleostean (otolithbased) species (Figure 11b). Sedimentary evidence of glacio-eustatic sea level rise correlated with MIS 19 and the Matuyama/Brunhes reversal is also clearly recognized in alluvial and shallow-marine depositional systems in widely different geographic areas (e.g. Pillans et al., 1998; Naish et al., 2005; Massari et al., 2007; Florindo et al., 2007), thus supporting the widespread traceability of this marine isotope stage.

\section{Conclusion}

The Vrica-Crotone and Montalbano Jonico sections are the only two astronomically-tuned marine records exposed on-land recovering the entire time interval subtended by the proposed Calabrian Stage. The composite record, excluding the Gelasian portion in the Vrica section, extends from the Calabrian GSSP (1.806 Ma) at the top of sapropel "e", MIS 65-64 transition and i-cycle 176, to the MIS 17-16 transition and i-cycle 60 (0.645 Ma). All the calcareous plankton bioevents occurring through the whole record are accurately tuned and their positions are strongly comparable with the available Mediterranean biochronology and oceanic data set.

The Vrica-Crotone section contains the proposed GSSP of the Calabrian Stage, located at the top of sapropel "e" and astronomically dated at $1.806 \mathrm{Ma}$ (Lourens et al., 2004). The Montalbano Jonico section contains the MIS 19 which closely corresponds to the Matuyama/Brunhes reversal, a guide criterion for the definition of the GSSP of the Early/Middle Pleistocene (Richmond, 1996; Pillans, 2003; Head and Gibbard, 2005). Despite the unreliable magnetostratigraphic record of the Montalbano Jonico section, for which full reasons are given (Sagnotti et al., 2010), we propose that the onset of MIS 19 represents a valuable horizon for the definition of the GSSP of the Middle Pleistocene in the section. Indeed, the sedimentary interval containing MIS 19 is very well exposed (Figure 11 ), is characterized by diverse and diagnostic fossil record and is chronologically constrained by means of multiple independent agesignificant tools. These features suggest that the Vrica-Crotone and Montalbano Jonico sections can be considered a suitable composite record for the Calabrian unit-stratotype.

\section{Acknowledgements}

The authors wish to thank Maria Bianca Cita, Philip Gibbard and Martin Head for their careful revision and valuable suggestions which greatly improved the manuscript. Maria Bianca Cita is doubly acknowledged for her good spirits in encouraging the research on Quaternary stratigraphy and her enthusiastic role in leading the proposal for the redefinition of the Calabrian Stage on behalf of the International Subcommission on Quaternary Stratigraphy. We are grateful to all researchers who have been intensively involved in the study of the Vrica section and whose contributions were very helpful for the accomplishment of the present paper. Constructive discussions with Marcello Tropeano have also improved the manuscript. Results on deep-sea cores are based on samples provided by the Deep-Sea Drilling Project (DSDP) and the Ocean Drilling Program (ODP). We are also grateful to Gert J. De Lange who made possible the sampling 
of Core KC01B at the Department of Earth Sciences - Geochemistry, Utrecht University. Maureen Raymo is greatly acknowledged for sending updated oxygen isotope chronology of Site 607 for the last 2 Ma. This study was financially supported by "Fondi Ateneo" 2009 (University of Bari) granted to R. La Perna. This work is ISMARBologna scientific contribution no.1703.

\section{References}

Aguirre, E., and Pasini, G., 1985, The Pliocene-Pleistocene Boundary: Episodes, v. 8, no. 2, pp. 116-120.

Aubry, M. P., Berggren,W.A., Van Couvering, J.A., McGowran, B., Hilgen, F., Steininger, F., and Lourens, L., 2009, The Neogene and Quaternary: chronostratigraphic compromise for non-overlapping magisteria?: Stratigraphy, v. 6, pp. 1-16.

Aubry, M. P., Berggren, W.A., Van Couvering, J.A. and Steininger, F., 1999, Problems in chronostratigraphy: stages, series, unit and boundary stratotypes, global stratotype section and point and tarnished golden spikes: Earth-Science Reviews, v. 46, pp. 99-148.

Azzaroli, A., Colalongo, M.L., Nakagawa, H., Pasini, G., Rio, D., Ruggieri, G., Sartoni, S. and Sprovieri, R., 1996, The Pliocene-Pleistocene boundary in Italy, in Van Couvering, J., ed., The Pliocene-Pleistocene boundary: Definition and Worlwide Correlation: Cambridge University Press, pp. 141-155.

Backman, J., Shackleton, N.J., and Tauxe, L., 1983, Quantitative nannofossil correlation to open ocean deep-sea sections from Plio-Pleistocene boundary at Vrica, Italy: Nature, v. 304, pp. 156-158.

Balduzzi, A., Casnedi, R., Crescenti, U., Mostrardini, F., and Tonna, M., 1982. Il Plio-Pleistocene del sottosuolo del bacino lucano (Avanfossa appenninica): Geologica Romana, v. 21, pp. 89-111.

Bassett, M.G., 1985, Towards a "Common Language" in Stratigraphy: Episodes, v. 8, no. 2, pp. 87-92.

Bassinot, F.C., Labeyrie, L.D., Vincent, E., Quidelleur, X., Shackleton, N.J., and Lancelot, Y., 1994, The astronomical theory of climate and the age of the Brunhes-Matuyama magnetic reversal: Earth and Planetary Science Letters, v. 126, pp. 91-108.

Bickert, T., Curry, W.B., and Wefer, G., 1997, Late Pliocene to Holocene (2.6-0 Ma) western equatorial Atlantic deep-water circulation: inferences from benthic stable isotope, in Shackleton, N.J., Curry, W.B., Richter, C., and Bralower, T.J., eds., Proceedings of the Ocean Drilling Program: Scientific Results, v. 154, College Station (TX), pp. 239-253.

Brilli, M., Lerche, I., Ciaranfi, N., and Turi, B., 2000, Evidences of precession and obliquity orbital forcing in oxygen-18 isotope composition of Montalbano Jonico Section (Basilicata, southern Italy): Applied Radiation and Isotopes, v. 52, pp. 957-964.

Capraro, L., Asioli, A., Backman, J., Bertoldi, R., Channell, J.E.T., Massari, F., and Rio, D., 2005, Climatic patterns revealed by pollen and oxygen isotope records across Brunhes-Matuyama Boundary in the Central Mediterranean (Southern Italy), in Head, M.J., and Gibbard, P.L., eds., Early-middle Pleistocene Transitions: The Land-Ocean Evidence: Geological Society of London, Special Publication 247, pp. 159-182.

Castradori, D., 1992, I nannofossili calcarei come strumento per lo studio biostratigrafico e paleoceanografico del Quaternario nel Mediterraneo Orientale. Unpublished Ph.D. Thesis, University of Milano, Italy.

Channell, J.E.T., Curtis, J.H., and Flower, B.P., 2004, The Matuyama-Brunhes boundary interval (500-900 ka) in North Atlantic drift sediments: Geophysical Journal International, v.158, pp. 489-505.

Ciaranfi, N., D' Alessandro, A., Girone, G., Maiorano, P., Marino, M., Soldani, D., and Stefanelli, S., 2001, Pleistocene sections in the Montalbano Jonico area and the potential GSSP for Early-Middle Pleistocene in the Lucania Basin (Southern Italy): Memorie Scienze Geologiche, v. 53, pp. 67-83.

Ciaranfi, N., Lirer, F., Lirer, L., Lourens, L.J., Maiorano, P., Marino, M., Petrosino, P., Sprovieri, M., Stefanelli, S. Brilli, M., Girone, A., Joannin,
S., Pelosi, N., and Vallefuoco, M., 2010, Integrated stratigraphy and astronomical tuning of Lower-Middle Pleistocene Montalbano Jonico land section (Southern Italy): Quaternary International, v. 219, pp. 109120

Ciaranfi, N., Marino, M., Sabato, L., D’Alessandro, A., and De Rosa, R., 1996, Studio geologico stratigrafico di una successione infra e mesopleistocenica nella parte sudoccidentale della Fossa Bradanica (Montalbano Jonico, Basilicata): Bollettino della Società Geologica Italiana, v. 15, pp. 379-391.

Cita, M.B., Capraro, L., Ciaranfi, N., Di Stefano, E., Lirer, F., Maiorano, P., Marino, M., Raffi, I., Rio, D., Sprovieri, R., Stefanelli, S., and Vai, G.B., 2008, The Calabrian Stage redefined: Episodes, v. 31, no 4, pp. 408419.

Cita, M.B., Capraro, L., Ciaranfi, N., Di Stefano, E., Marino, M., Rio, D., Sprovieri, R., and Vai, G.B., 2006, Calabrian and Ionian: A proposal for the definition of Mediterranean stages for Lower and Middle Pleistocene: Episodes, v. 29, no 2, pp. 107-114

Cita, M.B., and Castradori, D., 1995, Rapporto sul Workshop "Marine sections from the Gulf of Taranto (Southern Italy) usable as potential stratotypes for the GSSP of the Lower, Middle and Upper Pleistocene" (29 settembre - 4 ottobre 1994): Boll. Soc. Geol. It., v. 114, pp. 319-336.

Cita, M.B., and Pillans, B., 2010, Global stages, regional stages or no stages in the Plio/Pleistocene?: Quaternary International, v. 219, pp. 6-15.

Coe, R.S., Singer, B.S., Pringle, M.S., and Zhao, X., 2004, MatuyamaBrunhes reversal and Kamikatsura event on Maui: paleomagnetic directions, ${ }^{40} \mathrm{Ar} /{ }^{39} \mathrm{Ar}$ ages and implications: Earth and Planetary Science Letters, v. 222, pp. 667-684.

Colalongo, M.L., Pasini, G., and Sartoni, S., 1980, Neogene-Quaternario e definizione del relativo stratotipo: Paleontologia Stratigrafica ed Evoluzione, v. I, pp. 91-94.

D'Alessandro, A., La Perna, R., and Ciaranfi, N., 2003, Response of macrobenthos to changes in palaeoenvironments in the Lower-Middle Pleistocene (Lucania Basin, Southern Italy): Il Quaternario, Italian Journal of Quaternary Sciences, v. 16, pp. 167-182.

Emeis, K.-C., Robertson, A.H.F., Richter, C., et al., 1996, Proceedings of the Ocean Drilling Program: Initial Reports., v. 160, College Station, TX.

Florindo, F., Karner, D., Marra, F., Renne, P., Roberts, A., and Weaver, R., 2007, Radiometric age constraints for glacial terminations IX and VII from aggradational sections of the Tiber River delta in Rome, Italy: Earth and Planetary Science Letters, v. 256, pp. 61-80.

Gibbard, P., and Head, M.J., 2009, The definition of the Quaternary System/ Era and the Pleistocene Series/Epoch: Quaternaire, v. 20, no. 2, pp. 125133.

Gibbard, P.L., and Head, M.J., 2010, The newly-ratified definition of the Quaternary System/Period and redefinition of the Pleistocene Series/ Epoch, and comparison of proposals advanced prior to formal ratification: Episodes, v. 33, pp. 152-158.

Gibbard P.L., Head M.J., and Walker M.J.C., 2010. Formal ratification of the Quaternary System/Period and the Pleistocene Series/Epoch with a base at 2.58 Ma, Journal of Quaternary Science: v. 25, no 2, pp. 96-102.

Girone, A., and Varola, A., 2001, Fish otoliths from the Middle Pleistocene deposits of Montalbano Jonico (Southern Italy): Bollettino della Società Paleontologica Italiana, v. 40, no 3, pp. 431-443.

Head, M.J., and Gibbard, P.L., 2005, Early-Middle Pleistocene transitions: an overview and recommendation for the defining boundary, in Head, M.J. and Gibbard, P.L., eds, Early-Middle Pleistocene transitions: the land-ocean evidence: Geological Society of London, Special Publication, v. 247 , pp. $1-18$

Head, M.J., Gibbard, P., and Salvador, A., 2008a, The Quaternary: its character and definition: Episodes, v. 31, no.2, pp. 234-238.

Head, M.J., Pillans, B., and Farquhar, S.A., 2008b, The Early-Middle Pleistocene Transition: characterization and proposed guide for the defining boundary: Episodes, v. 31, no 2, pp. 255-259.

Hedberg, H.D., 1958, Stratigraphic classification and terminology: Am. Assoc. Pet. Geol. Bull., v. 42, pp. 1881- 1896.

Hilgen, F.J., Abels H.A., Iaccarino, S., Krijgsman, W., Raffi, I., Sprovieri, R., 
Turco, E., and Zachariasse, W.J., 2009, The Global Stratotype Section and Point (GSSP) of the Serravallian Stage (Middle Miocene): Episodes, v. 32, no 3, pp. $152-166$.

Hilgen, F.J., Brinkhuis, H., and Zachariasse, W.J., 2006, Unit stratotypes for global stages: The Neogene perspective: Earth-Science Reviews, v. 74, pp. 113-125.

Howell, M.H., Rio, D., and Thunell, R., 1990, Laminated sediments from the Vrica section (Calabria, southern Italy): evidence for Plio-Pleistocene warming and cooling trends in the Mediterranean region: Paleogeography, Paleoclimatology, Paleoecology, v. 78, pp. 195-216.

Howell, M.W., Thunell, R.C., Di Stefano, E., Tappa, E.J., and Sakamoto, T., 1998, Stable isotope chronology and paleoceanography history of Sites 963 and 964, eastern Mediterranean Sea: in Robertson, H.F., Emeis, K., Richter, C., et al. eds., Proceedings of the Ocean Drilling Program: Scientific Results, v. 160. College Station (TX), pp. 67-180.

Karner, D.B., Marra, F., and Renne, P., 2001, The history of the Monti Sabatini and Alban Hills volcanoes: groundwork for assessing volcanic-tectonic hazards for Rome: J. Volcanol. Geotherm. Res., v. 107, pp. 185-219.

Kroon, D., Alexander, I., Little, M., Lourens, L.J., Mattehewson, A., Robertson, A.H.F., and Sakamoto, T., 1998, Oxygen isotope and sapropel stratigraphy in the eastern Mediterranean during the last 3.2 million years, in Robertson, H.F., Emeis, K.C., Richter, C., et al., eds., Proceedings of the Ocean Drilling Program: Scientific Results, v. 160, College Station (TX), pp. 181- 190

Laskar, J., Joutel, F., and Boudin, F., 1993, Orbital, precessional, and insolation quantities for the Earth from $-20 \mathrm{Myr}$ to $+10 \mathrm{Myr}$ : Astron. Astrophys., v. 270, pp. 522- 533 .

Laskar, J., Robutel, P., Joutel, F., Gastineau, M., Correia, A.C.M., and Levrard, B., 2004, A long-term numerical solution for the insolation quantities of the Earth: Astronomy and Astrophysics, v. 428, pp. 261-285.

Lisiecki, L., and Raymo, M., 2005, A Pliocene-Pleistocene stack of 57 globally distributed benthic $\mathrm{d}^{18} \mathrm{O}$ records: Paleoceanography, v. 20, PA 1003.

Lourens, L.J., 2004, Revised tuning of Ocean Drilling Program Site 964 and KC01B Mediterranean) and implications for the $\mathrm{d}^{18} \mathrm{O}$, tephra, calcareous nannofossil, and geomagnetic reversal chronologies of the past $1.1 \mathrm{Myr}$ : Paleoceanography, v. 19, PA3010.

Lourens, L.J., Hilgen, F.J., and Raffi, I., 1998, Base of large Gephyrocapsa and astronomical calibration of early Pleistocene sapropels in Site 967 and Hole 969D: solving the chronology of the Vrica section (Calabria, Italy), in Robertson, H.F., Emeis, K., Richter, C., et al., eds., Proceedings of the Ocean Drilling Program: Scientific Results, v. 160, pp. 191-198. College Station, TX.

Lourens, L.J., Hilgen, F.J., Raffi, I., and Vergnaud-Grazzini, C., 1996, Early Pleistocene chronology of the Vrica section (Calabria, Italy): Paleoceanography, v. 11, no. 6, pp. 797-812.

Lourens, L., Hilgen, F., Shackleton, N. J., Laskar, J., and Wilson, D., 2004, The Neogene Period, in Gradstein, F. M., Ogg., J. G., and Smith, A. G., eds, A Geological Time Scale: Cambridge University Press, pp. 409440.

Maiorano, P., Aiello, G., Barra, D., Di Leo, P., Joannin, S., Lirer, F., Marino, M., Pappalardo, A., Capotondi, L., Ciaranfi, N., and Stefanelli, S., 2008, Paleoenvironmental changes during sapropel 19 (i-cycle 90) deposition: evidences from geochemical, mineralogical and micropaleontological proxies in the mid-Pleistocene Montalbano Jonico land section (Southern Italy): Palaeogeography, Palaeoclimatology, Palaeoecology, v. 257, no 3, pp. 308-334.

Maiorano, P., and Marino, M., 2004, Calcareous nannofossil bioevents and environmental control on temporal and spatial patterns at the early-middle Pleistocene: Marine Micropaleontology, v. 53, pp. 405-422.

Maiorano, P., Marino, M., Di Stefano, E., and Ciaranfi, N., 2004, Calcareous nannofossil events in the Lower-Middle Pleistocene transition at the Montalbano Jonico Section and ODP Site 964: calibration with isotope and sapropel stratigraphy: Rivista Italiana di Paleontologia e Stratigrafia, v. 110 , no. 2 , pp. $547-557$.

Marino, M., 1996, Quantitative calcareous nannofossil biostratigraphy of the lower-middle Pleistocene Montalbano Jonico section (southern Italy): Palaeopelagos, v. 6, pp. 534-541.

Massari, F, Capraro, L., and Rio, D., 2007, Climatic modulation of timing of system-tract development with respect to sea-level changes (Middle
Pleistocene of Crotone, Calabria, Southern Italy): Journal of Sedimentary Research, v. 77, pp. 461-468.

McGowran, B., Berggren, B., Hilgen, F., Steininger, F., Aubry, M.P., Lourens, L., and Van Couvering, J., 2009, Neogene and Quaternary coexisting in the geological time scale: The inclusive compromise: Earth-Science Reviews, v. 96, pp. 249-262.

Mix, A.C., Pisias, N.G., Rugh, W., et al., 1995b, Benthic foraminiferal stable isotope record from Site 849: 0-5 Ma, in Pisias, N.G., Mayer, L., Janecek, T., Palmer-Julson, A., and van Andel, T.H., eds., Proceedings of the Ocean Drilling Program: Scientific Results, v. 138, College Station (TX), pp. 371-412.

Mix, A.C., Le, J., and Shackleton, N.J., 1995a, Benthic foraminifer stable isotope stratigraphy of Site 846: 0-1.8 Ma, in Pisias, N.G., Mayer, L., Janecek, T., Palmer-Julson, A., and van Andel, T.H., eds., Proceedings of the Ocean Drilling Program: Scientific Results, v. 138, College Station (TX), pp. 839-856.

Naish, T. R., Field, B. D., Zhu1, H., Melhuish, A. Carter, R. M., Abbott S. T., Edwards S., Alloway, B. V. Wilson G. S., Niessen, F. Barker, A. Browne, G. H. and Maslen, G., 2005, Integrated outcrop, drill core, borehole and seismic stratigraphic architecture of a cyclothemic, shallow-marine depositional system, Wanganui Basin, New Zealand: Journal of the Royal Society of New Zealand, v. 35, no.1-2, pp 91-122.

Pasini, G., and Colalongo, M.L., 1982, Status of research on the Vrica section (Calabria, Italy), the proposed Neogene/Quaternary boundary-stratotype section, in Report at XI INQUA Congress, 1982, Pitagora-Tecnoprint, pp. 1-75.

Peccerillo, A., 2005, Plio-Quaternary volcanism in Italy: Petrology, Geochemistry, Geodynamics, Springer, Heidelberg, 365 pp.

Pillans, B., 2003, Subdividing the Pleistocene using the Matuyama-Brunhes boundary (MBB): an Australasian perspective: Quaternary Science Reviews, v. 22, pp. 1569-1577.

Pillans, B., Chappell, J., and Naish, T.R., 1998, A review of the Milankovitch climatic beat: template for Plio-Pleistocene sea-level changes and sequence stratigraphy: Sedimentary Geology, v. 122, pp. 5-21.

Quidelleur, X., Carlut, J., Soler, V., Valet, J.-P., and Gillot, P.-Y., 2003, The age and duration of the Matuyama-Brunhes transition from new $\mathrm{K}-\mathrm{Ar}$ data from La Palma (Canary Islands) and revisited ${ }^{40} \mathrm{Ar} /{ }^{39} \mathrm{Ar}$ ages: Earth and Planetary Science Letters, v. 208, pp. 149-163.

Raffi, I., 2002, Revision of the early-middle Pleistocene calcareous nannofossil biochronology (1.75-0.85 Ma): Marine Micropaleontology, v. 45, pp. $25-55$.

Raffi, I., Backman, J., Fornaciari, E., Pälike, H., Rio, D., Lourens, L., and Hilgen, F., 2006, A review of calcareous nannofossil astrobiochronology encompassing the past 25 million years: Quaternary Science Reviews, v. 25, pp. 3113-3137.

Raffi, I., Backman, J., Rio, D., and Shackleton, N.J., 1993, Early Pleistocene and late Pliocene nannofossil biostratigraphy and calibration to oxygen isotope stratigraphies from DSDP Site 607 and ODP Site 677: Paleoceanography, v. 8, pp. 387-404.

Remane, J., Bassett, M.G., Cown, J.W., Gohrbandt, K.H., Lane, H.R., Michelsen, O., and Naiwen, W., 1996, Revised guidelines for the establishment of global chronostratigraphic standards by the International Commission on Stratigraphy (ICS): Episodes, v.19, no. 3, pp. 77-81.

Richmond, G.M., 1996. The INQUA-approved provisional Lower-Middle Pleistocene boundary, in Turner, C., ed., The Early Middle Pleistocene in Europe, pp. 319-326, Balkema, Rotterdam.

Rio, D., Raffi, I., and Backman, J., 1997, Calcareous nannofossil biochronology and the Pliocene-Pleistocene boundary, in Van Couvering, J.A., ed., The Pleistocene Boundary and the Beginning of the Quaternary: Cambridge University Press, pp. 63-78.

Rio, D., Raffi, I., and Villa, G., 1990, Pliocene-Pleistocene calcareous nannofossil distribution patterns in the western Mediterranean, in Kastens, K.A., Mascle, J., et al., eds., Proceedings of the Ocean Drilling Program: Scientific Results, v. 107, College Station (TX), pp. 513-533.

Rio, D., Sprovieri, R., Di Stefano, E., Capraro, L., Pasini, G., Vai, G.B., Iaccarino, S., Raffi, I., Raffi, S. et al., 2010, The Gelasian Stage and the base of the Pleistocene querelle, in La nuova scala del Quaternario: implicazioni e sviluppi futuri, workshop nazionale 17-18 giugno, 2010, Roma, Abstract. 
Roberts, A. P., Florindo, F., Larrasoaña, J.C., O'Regan M.A., and Zhao, X., 2010, Complex polarity pattern at the former Plio-Pleistocene global stratotype section at Vrica (Italy): remagnetization by magnetic iron sulphidhes: Earth and Planetary Science Letters, v. 292, pp. 98-111.

Rossignol-Strick, M., Paterne, M., Bassinot, F., Emeis, K.-C., and De Lange, G. J., 1998, An unusual mid-Pleistocene monsoon period over Africa and Asia: Nature, v. 392, pp. 269-272.

Ruddiman, W.F., Raymo, M.E., Martinson, D.G., Clement, B.M., and Backman, J., 1989, Pleistocene evolution: Northern Hemisphere ice sheets and North Atlantic Ocean: Paleoceanography, v. 4, pp. 353-412.

Sagnotti, L., Cascella, A., Ciaranfi, N., Macrì, P., Maiorano, P., Marino, M., and Taddeucci, J., 2010, Rock magnetism and paleomagnetism of the Montalbano Jonico section (Italy): evidence for late diagenetic growth of greigite and implications for magnetostratigraphy: Geophysical Journal International, v. 180, pp. 1049-1066.

Salvador, A., 1994, International Stratigraphic Guide, 2nd edition: International Union of Geological Sciences and the Geological Society of America, Trondheim, Norway, and Boulder, Colorado, 214 pp.

Selli, R., Accorsi, C.A., Bandini Mazzanti, M., Bertolani Marchetti, D., Bonadonna, F.P., Borsetti, A.M., Cati, F., Colalongo, M.L., d'Onofrio, S., Landini, W., Menesini, E., Mezzetti, R., Pasini, G., Savelli, G., and Tampieri, R., 1977, The Vrica section (Calabria). A potential NeogeneQuaternary boundary stratotype: Giornale di Geologia, v. 41, pp. 181204.

Shackleton, N.J., Berger, A., and Peltier, W.R., 1990, An alternative astronomical calibration of the lower Pleistocene timescale based on ODP Site 677: Transactions of the Royal Society of Edinburgh-Earth Science, v. 81 , pp. 251-261.

Shackleton, N.J., Crowhurst, S., Hagelberg, T., Pisias, N.G., and Schneider, D.A., 1995, A new late Neogene time scale: application to Leg 138 sites, in Pisias, N.G., Mayer, L., Janecek, T., Palmer-Julson, A., and van Andel, T.H., eds., Proceedings of the Ocean Drilling Program: Scientific Results, v. 138 pp. $73-101$.

Singer, B.S., Jicha, B.R., Kirby, B.T., Geissman, J.W., and Herrero-Bervera, E., 2008, ${ }^{40} \mathrm{Ar} /{ }^{39} \mathrm{Ar}$ dating links Albuquerque Volcanoes to the Pringle Falls excursion and the Geomagnetic Instability Time Scale: Earth and Planetary Science Letters, v. 267, pp. 584-595.

Smith, M.E., Carrol, A.R., and Singer, B.S., 2008, Synoptic reconstruction

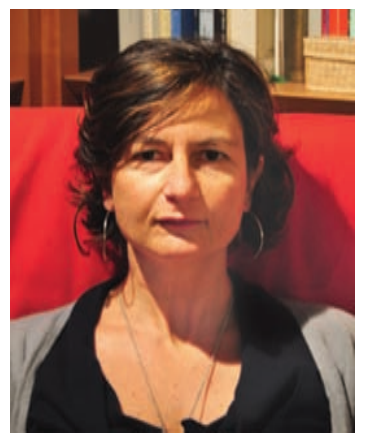

Patrizia Maiorano is a Researcher in Paleontology and Paleoecology at the Department of Geology and Geophysics of University of Bari, Italy and is a calcareous nannofossil specialist. She has mainly worked on Mediterranean and extra-Mediterranean Neogene and Quaternary biostratigraphy and biochronology in deep-sea cores and in Southern Apennine marine deposits.

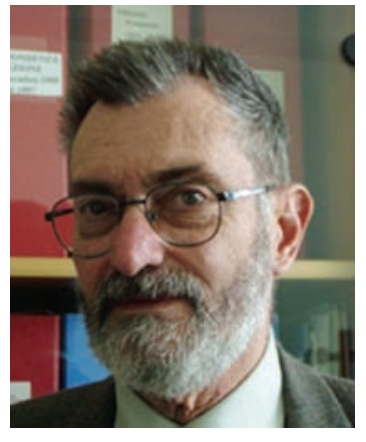

Neri Ciaranfi, presently retired, was professor of Geology and Quaternary Geology at the University of Bari, Italy. His interests cover Stratigraphy and Neotectonics. He is a member of Italian Commission on Stratigraphy. His scientific activity mainly concerns integrated stratigraphy of marine Quaternary deposits, with particular regard to Southern Apennines foredeep deposits. of a major ancient lake system: Eocene Green River Formation, western United States: Geological Society of America Bulletin, v. 120, no 1-2, pp. 54-84

Sprovieri, R., Di Stefano, E., Howell, M., Sakamoto, T., Di Stefano, A., and Marino, M., 1998, Integrated calcareous plankton biostratigraphy and cyclostratigraphy at Site 964, in Robertson, A.H.F., Emeis, K.C., Richter, C., and Camerlenghi, A., eds., Proceedings of the Ocean Drilling Program: Scientific Results, v. 160. College Station, (TX), pp. 155- 165.

Stefanelli, S., 2003, Benthic foraminiferal assemblages as tools for paleoenvironmental reconstruction of the early-middle Pleistocene Montalbano Jonico composite section: Bollettino della Società Paleontologica Italiana, v. 42, pp. 281-299.

Stefanelli, S., 2004, Cyclic changes in oxygen based on foraminiferal microhabitats: Early-Middle Pleistocene, Lucania Basin (southern Italy): Journal of Micropaleontology, v. 23, pp. 81-95.

Stefanelli, S., Capotondi, L., and Ciaranfi, N., 2005, Foraminiferal record and environmental changes during the deposition of the early-middle Pleistocene sapropels in southern Italy: Palaeogeography, Palaeoclimatology, Palaeoecology, v. 216, pp. 27-52.

Suc, J.P., Combourieu-Nebout, N., Seret, G., Popescu, S. M., Klotz, S., Gautier, F., Clauzon, G., Westgate, J., Insinga, D., and Sandhu, A.S., 2010, The Crotone series: A synthesis and new data: Quaternary International, v. 219, pp. 121-133.

Tauxe, L., Opdyke, N.D., Pasini, G.C., and Elmi, C., 1983, Age of the PlioPleistocene boundary in the Vrica section, Southern Italy: Nature, v. 304, pp. $125-129$.

Van Couvering, J.A., 1995, Setting Pleistocene marine stages: Geotimes, v. 40 , pp. $10-11$.

Zijderveld, J.D.A, Hilgen, F.J., Langereis, C.G., Verhallen, P.J.J.M., and Zachariasse, W.J., 1991, Integrated magnetostratigraphy and biostratigraphy of the Upper Pliocene-Lower Pleistocene from the Monte Singa and Crotone areas in Calabria (Italy): Earth Planetary Science Letters, v. 107, pp. 697-714.

Walsh, S.L., 2008, The Neogene: Origin, adoption, evolution, and controversy: Earth-Science Reviews, v. 89, pp. 42-72.

Walsh, S.L., Gradstein, F.M., and Ogg, J.G., 2004, History, philosophy, and application of the Global Stratotype Section and Point (GSSP): Lethaia, v. 37 , pp. $201-218$.

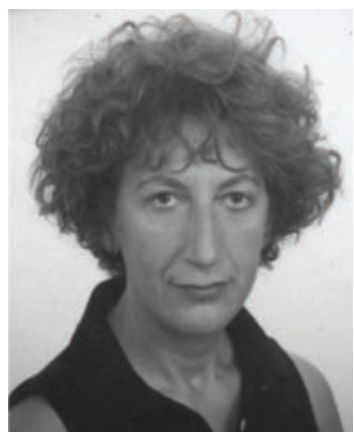

Maria Marino is Associate Professor in Paleontology and Paleoecology at the Department of Geology and Geophysics of Bari University, Italy. Her researches mostly focus on Micropaleontology by using calcareous nannofossils as biostratigraphical and paleoclimatical-paleoceanographical tool in Mediterranean and oceanic areas during the Pleistocene.

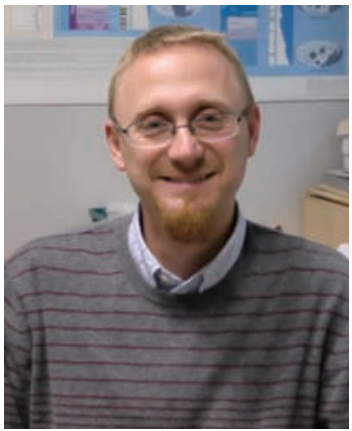

Fabrizio Lirer is the present secretary of the Regional Committee on Mediterranean Neogene Stratigraphy (RCMNS) and of the Italian Commission on Stratigraphy (CIS). His main research interests lie in the cyclostratigraphy and Neogene integrated biostratigraphy with special focus on the Mediterranean. He is a planktonic foraminiferal specialist. 